\title{
UTJECAJ SUBVENCIJA NA USPJEŠNOST POSLOVANJA SPECIFIČNE SKUPINE HRVATSKIH JAVNIH PODUZEĆA
}

S obzirom na to da je u strukturi hrvatskih instrumenata dodjele državnih potpora u odnosu na zemlje članice Europske unije dominantna zastupljenost državnih subvencija, cilj ovoga rada je analizirati utjecaj subvencija na uspješnost poslovanja specifične skupine hrvatskih javnih poduzeća u razdoblju od 2005. do 2015. godine. Riječ je o poduzećima koja su kroz životni vijek mijenjala svoj pravni i ekonomski identitet (spajanja, pripajanja i sl.), pretežito su u državnom vlasništvu i primila su znatne iznose državnih subvencija.

Podaci za analizu preuzeti su iz registra godišnjih financijskih izvještaja Financijske agencije. Promatraju se poduzeća koja su primila subvencije $u$ analiziranom razdoblju i to samo za godine u kojima su ih primila. Cilj je izmjeriti utjecaj primljenih subvencija na financijske rezultate specifične skupine poduzeća (HŽ, Holding, brodogradilišta). Kako se ovom temom bavilo vrlo malo inozemnih i domaćih istraživača, doprinos ovoga rada je u kvantifikaciji veza i testiranju statističkih modela da bi se utvrdila statistička povezanost utjecaja subvencija na financijske rezultate specifične skupine javnih poduzeća te korelacije nezavisnih varijabli, kao i nezavisnih sa zavisnim varijablama. Odabrane su dvije glavne nezavisne varijable (dva modela) za koje se procjenjuje utjecaj subvencija na financijske rezultate specifične skupine poduzeća u promatranom razdoblju, a to su prihodi od subvencija i udio prihoda od subvencija u aktivi poduzeća. Zavisne varija-

*A. Buneta, mr.sc., viši predavač, Međunarodno sveučilište Libertas (e-mail adresa: andelka. buneta1@gmail.com). Rad je primljen u uredništvo 05.08.2019. godine, a prihvaćen je za objavu 04.04.2020. godine. 
ble su: dobit/gubitak razdoblja, novostvorena vrijednost, koeficijent tekuće likvidnosti, koeficijent obrtaja imovine i broj zaposlenih temeljem sati rada. Na temelju rezultata provedene analize može se zaključiti da subvencije imaju utjecaj na uspješnost poslovanja specifične skupine javnih poduzeća u odnosu na modelsku procjenu, ponajprije na dobit/gubitak razdoblja, novostvorenu vrijednost, a najmanje na broj zaposlenih temeljem sati rada što implicira zaključak da su veće iznose subvencija dobivala poduzeća s većim brojem zaposlenih.

Kod rezultata istraživanja treba uzeti u obzir ograničenje koje proizlazi iz baze podataka, odnosno nedostatka jasne AOP pozicije o državnim subvencijama u godišnjim financijskim izvještajima (AOP pozicija uključuje subvencije, dotacije, poticaje i sl.) te se koristila dostupna pozicija.

Ključne riječi: javna poduzeća, specifična skupina javnih poduzeća, državne potpore, državne subvencije, uspješnost poslovanja

\section{UVOD}

Republika Hrvatska pripada državama Europske unije koje imaju visok udio državnih poduzeća u BDP-u (Bajo, Zuber i Primorac, 2017). Kako navode autori, Republika Hrvatska je 2016. godine u većinskom državnom vlasništvu imala 1149 poduzeća s tendencijom rasta u proteklih deset godina. ${ }^{1}$

Navedeno implicira da hrvatska državna poduzeća obavljaju različite državne poslove i provode financijske transakcije na zahtjev državnih jedinica kao njihovih vlasnika, ali bez jasne strategije i politike usmjerene u određene gospodarske djelatnosti koje proizlaze iz njihove važnosti za državu u cjelini. Upravo zbog toga državna poduzeća u hrvatskom gospodarstvu participiraju u gotovo svim gospodarskim djelatnostima, imaju česte statusne promjene i vrlo skroman doprinos financijskim prihodima državnog proračuna. Ujedno su vrlo česti korisnici državnih subvencija - bez obzira na to radi li se o zadovoljenju nekog od javnih interesa, pokriću gubitaka iz poslovanja ili očuvanju radnih mjesta.

Kako je riječ o vrlo značajnim financijskim sredstvima dodijeljenim kroz subvencije, intencija ovoga rada je istražiti utjecaj primljenih subvencija na uspješnost poslovanja specifične skupine hrvatskih javnih poduzeća. Ekonomsko vrednovanje uspješnosti u literaturi najčešće razmatra sljedeća ekonomska mjerila

1 Vlasnički portfelj državnih poduzeća u većinskom vlasništvu države 2005. godine iznosio je 1042 , a 2015. godine 1064 poduzeća. 
uspješnosti poslovanja poduzeća: proizvodnost rada, ekonomičnost, rentabilnost, akumulacijsku i reproduktivnu sposobnost poduzeća (Zelenika i Toković, 2000). Kao glavni kriteriji uspješnosti poslovanja najčešće se navode visina prihoda i dobit razdoblja. Dok visina prihoda odražava tržišnu poziciju poduzeća, dobit je mjera profitabilnosti poduzeća. Pokazatelji ekonomičnosti, profitabilnosti i investiranja smatraju se pokazateljima uspješnosti poslovanja. Stoga se u ovom radu uspješnost specifične skupine javnih poduzeća promatra kroz dobit/gubitak razdoblja, novostvorenu vrijednost, koeficijent tekuće likvidnosti, koeficijent obrtaja imovine i broj zaposlenih temeljem sati rada.

U recentnim istraživanjima autori uglavnom istražuju samo određene varijable financijske uspješnosti. Tako Girma, Gorg i Wagner (2009) istražuju vezu između subvencija vezanih za proizvodnju i izvoz u proizvodnim poduzećima Zapadne i Istočne Njemačke te zaključuju da subvencije nemaju jak utjecaj na izvoz. Njihova su zapažanja u korelaciji s rezultatima istraživanja Bernarda i Jensena (2004) provedenog u SAD-u koji također dolaze do zaključka da izdaci za promociju izvoza na državnoj razini nemaju značajniji utjecaj na izvoz na razini poduzeća.

Bergstrom (1998) ispituje učinke kapitalnih subvencija na produktivnost na razini švedskih poduzeća, dok se Beason i Weinstein (1996) koriste agregiranim podacima kako bi dobili dodatne informacije o učincima državne intervencije kroz subvencije. Za analizu učinaka švedske industrijske politike prikupili su skup podataka za subvencionirana i nesubvencionirana proizvodna poduzeća za razdoblje od 1987. do 1993. godine te ih usporedili i procijenili njihove proizvodne funkcije kontrolirajući različite čimbenike koji bi mogli utjecati na njihovu produktivnost. Istražili su postoje li razlike u produktivnosti između poduzeća u godinama nakon dodjele subvencija. Griffiths i Wall (2004) analizirali su utjecaj državnih subvencija na poslovanje poduzeća koja su ih primala s intencijom utvrđivanja veze ekonomskih prednosti korisnika subvencija u odnosu na poduzeća koja ih nisu primala, odnosno poslovala su prema tržišnim principima. Došli su do zaključka da iako su subvencionirana poduzeća bila u svojevrsnoj ekonomskoj prednosti u odnosu na nesubvencionirana poduzeća, nisu ostvarila posebne financijske efekte.

Kao što je već spomenuto, iz navedenog je vidljivo da autori uglavnom ispituju određene pojedine varijable uspješnosti, dok se u ovom radu analizira utjecaj subvencija na uspješnost poslovanja specifične skupine hrvatskih javnih poduzeća (koja su imala statusne promjene) s više varijabli u razdoblju od 2005. do 2015. godine u odnosu na ostala poduzeća koja su korisnici državnih subvencija. 


\section{POJMOVNO ODREĐENJE JAVNIH PODUZEĆA}

Pojam javna poduzeća (engl. public utilities, njem. öffentliche Versorgungsbetriebe, franc. service public) podrazumijeva da se radi o poduzećima u državnom vlasništvu te se često upotrebljava i izraz državna poduzeća.

Prema OECD-ovoj definiciji iz Smjernica korporativnog upravljanja, državnim poduzećima smatraju se sva društva u kojima je odgovornost države kao vlasnika ograničena udjelima u kapitalu, ali i organizacije osnovane prema posebnim propisima ako su njihovi ciljevi i aktivnosti ekonomske prirode (OECD, 2015b).

Prema definiciji MMF-a, javna poduzeća su ona poduzeća koja su u državnom vlasništvu ili se nalaze pod državnom kontrolom. Iz takve definicije javnih poduzeća proizlazi da i poduzeća u manjinskom državnom vlasništvu mogu biti javna poduzeća (Kesner-Škreb, 2006, str. 93-94).

Zakonom o proračunu (Narodne novine, 87/08, 136/12 i 15/15) javna poduzeća definiraju se kao pravne osobe u većinskom izravnom ili neizravnom državnom vlasništvu čije su dionice i poslovni udjeli u portfelju Republike Hrvatske ili u kojima Republika Hrvatska ima osnivačka (vlasnička) prava.

Pojam javnog poduzeća u sebi sadrži dvije komponente - javnost i tržišnost (Žunić Kovačević, 2008, str. 206).

Elementi javnosti ogledaju se kroz nekoliko važnih činjenica:

- glavne poslovne odluke donosi država kao vlasnik kapitala, pri čemu te odluke veže uz šire društvene interese i nisu isključivo motivirane ostvarivanjem dobiti (npr. socijalna politika)

- dobit/gubitak koji ostvaruju pripisuje se/odbija se ukupnim javnim prihodima/javnim rashodima putem državnog proračuna i pripada cijeloj društvenoj zajednici

- tijela javnog poduzeća odgovaraju za svoje poslovanje vlasniku, odnosno državi, predstavničkom tijelu (saboru) kao zaštitniku javnih interesa.

Element tržišnosti odnosi se na tržišno poslovanje javnih poduzeća od kojih se očekuje da budu financijski solventna u dugom roku te su stoga podložna stalnoj tržišnoj provjeri i da cijene njihovih usluga budu utemeljene na pokriću graničnih troškova poslovanja.

Mnogobrojni su razlozi osnivanja javnih poduzeća. Neosporno je da je najveći razlog tržišni neuspjeh, odnosno činjenica da bi takva poduzeća bez državnog utjecaja poslovala nerentabilno (prirodni monopoli koji bi bez državne regulacije proizvodili nedovoljnu količinu proizvoda uz visoku cijenu), te stoga ne čudi činjenica da se takva poduzeća nalaze u javnim komunalnim uslugama poput pro- 
meta, vodoopskrbe, transportnih usluga, elektroopskrbe ili se radi o „strateškim“ sektorima kako bi država putem njih utjecala na zaposlenost te povećala štednju i investicije. Često pružaju usluge na nekomercijalnoj osnovi, što podrazumijeva da su cijene niže od onih potrebnih za pokrivanje troškova, ili se radi o socijalnim uslugama. Upravo se zbog toga financiraju raznim vrstama subvencija ili se gubitak iz poslovanja pokriva iz državnog proračuna.

Prema organizacijskom obliku, javna poduzeća u Republici Hrvatskoj organizirana su kao dionička društva ili društva s ograničenom odgovornošću, a dijele se na financijska i nefinancijska. Zajedničko im je vlasništvo i/ili kontrola države.

Financijska javna poduzeća dijele se na monetarna i nemonetarna. Monetarna javna poduzeća čine financijska ili, „kvazifinancijska“ poduzeća i tržišne neprofitne institucije. Zajednička im je karakteristika da su pod kontrolom jedinica opće države. To su primjerice: Hrvatska narodna banka, Hrvatska poštanska banka, Hrvatska banka za obnovu i razvoj.

Nemonetarna financijska javna poduzeća su financijska društva pod kontrolom jedinica opće države (osim javnih depozitarnih društava i središnje banke). Ona su u pravilu kombinacija nefinancijskih i nemonetarnih financijskih javnih poduzeća kao što su Hrvatska agencija za nadzor nefinancijskih usluga, Financijska agencija, Središnje klirinško depozitarno društvo (Buturac, 2014).

Nefinancijska javna poduzeća uglavnom pružaju usluge od posebnoga državnog interesa na nekomercijalnoj osnovi, vrlo često po nižim cijenama od graničnih troškova poslovanja (npr. plaćanje struje po cijeni nižoj od tržišne cijene za seoska kućanstva) ili pružaju određene socijalne usluge. Većinom se nekomercijalne aktivnosti financiraju unakrsnim subvencioniranjem različitih skupina potrošača (za istu uslugu neki potrošači plaćaju višu, a neki nižu cijenu) ili se njihov gubitak pokriva iz državnog proračuna što narušava transparentnost sustava (Bejaković, Vukšić i Bratić, 2011). Najpoznatija nefinancijska javna poduzeća u Republici Hrvatskoj su Hrvatska lutrija, Hrvatska elektroprivreda i Hrvatske šume.

\subsection{Specifičnosti poslovnog okruženja javnih poduzeća}

U odnosu na ostale poslovne subjekte javna poduzeća djeluju u specifičnom poslovnom okruženju. Ponajprije ono proizlazi iz monopolističkog ili oligopolskog položaja tih poduzeća, ali i potpora države te zakonske regulative. Državna intervencija u njihovo poslovanje uglavnom se očituje kroz zakonsku regulativu, dodjelu financijske pomoći, izravne investicije ili porezne olakšice. Upravo zbog toga opstanak im nije upitan, ali uspješnost njihova poslovanja uvelike ovisi o 
upravljačkoj sposobnosti menadžmenta koji se nerijetko postavlja po političkom ključu. S druge strane njihove su djelatnosti strogo određene što im onemogućuje širenje poslovanja u nove gospodarske djelatnosti i/ili inozemstvo. U slučaju nedostatka financijskih sredstava potreban iznos često se alocira iz državnog proračuna, a u slučaju pozitivnoga financijskog rezultata (ostvarivanja dobiti) u skladu s internim aktima dio dobiti se uplaćuje u državni proračun te ima korektivnu funkciju financijskog poslovanja javnih poduzeća.

Većina javnih poduzeća u odnosu na ostala poduzeća svoju konkurentsku prednost crpi ponajprije iz monopolističkog položaja i visoko postavljene barijere ulaska na tržište novim tržišnim ,igračima“, posebno u kapitalno intenzivnim djelatnostima kao što su ceste, željeznice i sl. U pravilu kupcima nude nešto jedinstveno i osobito vrijedno za njih što im drugi proizvođači u istoj gospodarskoj djelatnosti ne mogu ponuditi.

Oligopolni položaj javnih poduzeća proizlazi iz činjenice da ih je liberalizacija tržišta i ulazak konkurencije doveo u položaj da više nisu isključivi pružatelji usluga na tržištu. Konkurenti u privatnom vlasništvu često pružaju usluge u profitabilnijem dijelu djelatnosti, za razliku od javnih poduzeća koja moraju pružati usluge i u neprofitabilnom segmentu. Tipičan primjer za to je Jadrolinija koja je obvezna održavati određeni vozni red bez obzira na to je li ruta ovisno o sezoni i broju putnika profitabilna, dok neki privatni brodari vozni red utvrđuju samo na profitabilnim rutama (Žager i Žager, 2008, str. 338).

Specifičnost poslovnog okruženja javnih poduzeća u odnosu na privatna poduzeća očituje se kroz sljedeće bitne čimbenike:

- monopolski položaj - radi se o poduzećima koja su često prirodni monopoli, odnosno jedini pružatelji određene usluge na tržištu

- regulatorno određenje - uz općenitu zakonsku regulativu vezanu za poslovanje trgovačkih društava javna poduzeća regulirana su posebnim zakonskim aktima

- strateški značaj - djelatnosti s kojima se bave za državu vrlo često imaju stratešku važnost, posebno kada je riječ o cestovnoj infrastrukturi, telekomunikacijama i opskrbi energentima te pitkom vodom

- kontrola poslovanja - osim unutarnje revizije (financijske kontrole) i vanjske revizije koje su obveznici zbog svoje veličine, ova su poduzeća obveznici i državne revizije, a ako se radi o korisnicima proračuna, podložna su i proračunskom nadzoru Ministarstva financija

- tijela poduzeća - izbor članova uprave i nadzornih odbora političke je prirode

- dvostruka uloga države - država je istovremeno i regulator i pružatelj usluge zbog čega je moguć sukob interesa 
- siguran kontinuitet poslovanja - poslovni neuspjeh ne sankcionira se otvaranjem stečaja nad društvom već se gubici pokrivaju iz proračuna, što znači da je kontinuitet poslovanja zajamčen

- intervencija države - očituje se u određivanju cijena, izravnim investicijama, proračunskim sredstvima za poslovanje i otplatu kredita te jamstvima za obveze

- položaj na tržištu kapitala - na tržištu kapitala ova društva često imaju povlašten položaj zbog percepcije kreditora da će država uvijek jamčiti za njihove obveze, čak kada takva jamstva nisu izdana i nisu nigdje normirana u pozitivnim propisima; na ocjenu njihove kreditne sposobnosti na inozemnim tržištima kapitala presudan utjecaj ima kreditni rejting Republike Hrvatske (Žager i Žager, 2008, str. 339).

Analiza iz Izvješća za Hrvatsku (Europska komisija, 2017) pokazuje da je glavno obilježje poduzeća u državnom vlasništvu slaba produktivnost te da je razlika u produktivnosti poduzeća u državnom vlasništvu i sličnih poduzeća u privatnom sektoru najveća u odnosu na sve zemlje srednje i istočne Europe. Osim što nominalno umanjuju prosječnu produktivnost u sektorima u kojima posluju, zbog njihove je istaknute prisutnosti ograničena alokativna učinkovitost tržišta jer se produktivni resursi preusmjeravaju od učinkovitijih poduzeća. U nacionalnim programima reformi iz nekoliko proteklih godina prepoznata je važnost smanjenja državnoga vlasništva privatizacijom poduzeća koja nisu od strateškoga ili posebnoga interesa za državu te unaprjeđenja korporativnoga upravljanja u društvima koje država zadrži u vlasništvu. No obveze koje su u tom smislu preuzete samo su djelomično ispunjene.

Javna poduzeća suočavaju se i s mnogim ograničenjima posebno u vezi s korporativnim upravljanjem koje ponajprije proizlazi iz odvojenosti vlasništva (država/grad je vlasnik u ime građana) od upravljanja. Situaciju usložnjava i neizbježna činjenica da mnoga državna tijela imaju utjecaj na poduzeća u državnom vlasništvu (jedno ili više ministarstava, vlada, državne agencije kreirane za upravljanje državnim vlasništvom, sabor) i stoga mogu ,iskorištavati“ državna poduzeća kako bi promovirali neke svoje kratkoročne političke ciljeve, potkopavajući njihovu učinkovitost i otvarajući vrata korupciji (Crnković, 2011, str. 279-292) i/ili pogodovanju pojedinim interesnim skupinama.

\subsection{Specifična skupina javnih poduzeća}

Specifičnom skupinom poduzeća u ovom istraživanju smatraju se oni poslovni subjekti koji su tijekom promatranog razdoblja imali neke od statusnih promjena u vidu spajanja, pripajanja, razdvajanja i slično. Riječ je o promjenama njihova 
pravnog i ekonomskog identiteta, bilo da se radilo o stvaranju većih ili manjih poslovnih subjekata jer se spajaju ili pripajaju ili se radilo o cijepanju i stvaranju više poslovnih entiteta. Pretežito su to poduzeća u državnom vlasništvu koja su preživjela brojne statusne izmjene, a i primila znatne iznose državnih subvencija.

Da se radi o vrlo specifičnoj skupini poduzeća s turbulentnim i čestim statusnim izmjenama ilustrirat će nekoliko primjera.

Primjer su Hrvatske željeznice koje se izdvajaju po iznosu primljenih subvencija u odnosu na ostala poduzeća iz specifične skupine poduzeća. Republika Hrvatska osnovala je Hrvatske željeznice kao trgovačko društvo s ograničenom odgovornošću Zakonom o izmjenama i dopunama Zakona o hrvatskim željeznicama (Narodne novine, 162/98) i to kao pravni slijednik društva osnovanog Zakonom o hrvatskim željeznicama (Narodne novine, 53/94).

HŽ - Hrvatske željeznice d.o.o. poslovale su do 6. ožujka 2007. godine kada su razdvojene na više pravnih osoba, odnosno trgovačkih društava: HŽ Infrastruktura d.o.o., HŽ Vuča vlakova d.o.o., HŽ Putnički prijevoz d.o.o. i HŽ Cargo d.o.o. HŽ Vuča vlakova d.o.o. u međuvremenu je, odnosno 5. studenog 2012. godine, prestalo postojati i brisano je iz sudskog registra.

Sličan scenarij doživio je i Zagrebački električni tramvaj d.o.o. koji je 2006. godine pripojen trgovačkom društvu Gradsko komunalno gospodarstvo d.o.o., kao i druga društva ${ }^{2}$ koja posluju pod nazivom Zagrebački holding d.o.o., da bi 2015. godine ponovno bio izdvojen i posluje kao samostalno trgovačko društvo.

Ovi primjeri ilustriraju vrlo specifično poslovno okruženje ove podskupine javnih poduzeća u odnosu na ostale poslovne subjekte gdje vlasnik (država/grad) izravnom intervencijom kroz zakonsku ili podzakonsku regulativu ili izravnim subvencioniranjem mijenja poslovnu stvarnost promatranih poduzeća utječe na njihovu opstojnost iz dnevnopolitičkih i drugih razloga.

\section{SUBVENCIJE I DRŽAVNE POTPORE}

Kako je pitanje subvencija i državnih potpora vrlo široko, u ovom se radu elaboriraju elementi financiranja specifičnih javnih poduzeća putem subvencija.

S obzirom na to da u europskom i hrvatskom zakonodavstvu nema jednoznačne definicije državnih potpora i subvencija te je potrebno u svakom pojedinačnom slučaju ocijeniti radi li se o državnoj potpori ili ne, ${ }^{3}$ predmetno istraživanje nema in-

\footnotetext{
${ }^{2}$ https://www.zgh.hr/o-nama-7/podruznice-trgovacka-drustva-i-ustanove-2176/2176

${ }^{3} \mathrm{U}$ tu svrhu služe jedinstveni kriteriji koji trebaju biti ispunjeni kumulativno. Više na http:// www.mfin.hr/drzavne-potpore (pristup 10.07.2019.)
} 
tenciju elaboriranja pojmovnoga određenja državnih potpora i subvencija bez obzira na njegov neosporni značaj. Iz pojmovnoga određenja proizlazi ne samo različit obuhvat instrumenata kojima se države koriste u podupiranju svojih gospodarstava (što otežava uspoređivanje objavljenih podataka iz različitih izvora) već i uspostavljanje sustava kontrole potpora u državama članicama ili u Europskoj uniji kao cjelini.

Državne potpore u svim članicama Europske unije uređene su nadnacionalnim sustavom objedinjenim u Europskoj komisiji, koji se preko nacionalnih tijela uspostavlja definicijom, kategorizacijom, regulativom i smjernicama državnih potpora (Spevec, 2012) u zemljama članicama. Tako je i Republika Hrvatska nakon stjecanja punopravnoga članstva 2013. godine uredila državne potpore na temelju svih zahtjeva i usmjerenja koje je Komisija postavila.

Uvela je politiku državnih potpora kao novi mehanizam kojim u trogodišnjim razdobljima postavlja prioritetne ciljeve pri dodjeli državnih potpora te svrhu učinkovitoga korištenja sredstava državnoga proračuna. Osnovni instrument toga mehanizma su Smjernice politike državnih potpora ${ }^{4}$ - svojevrsne upute kojima se trebaju voditi davatelji državnih potpora (osim davatelja državnih potpora jedinica lokalne, područne i regionalne samouprave) pri planiranju i izradi novih prijedloga državnih potpora.

Prioritetni cilj politike državnih potpora u Republici Hrvatskoj i nadalje je smanjivati udio sektorskih potpora u ukupno dodijeljenim državnim potporama $\mathrm{u}$ korist horizontalnih kako bi se u što većoj mjeri približila razini usporedivosti s onom u Europskoj uniji. Dok Europska unija u horizontalne potpore ulaže 84 posto potpora namijenjenih industriji i uslugama, Republika Hrvatska ulaže samo 25 posto. ${ }^{5}$ Kretanje sektorskih potpora u Republici Hrvatskoj u pravilu je posljedica spašavanja pojedinih gospodarskih sektora kao što su brodogradnja, promet, Hrvatska radiotelevizija te će trebati još puno vremena da bi dosegnula europski prosjek.

\section{METODOLOŠKI OKVIR}

Predmetno istraživanje analizira podatke o subvencijama iz godišnjih financijskih izvješća poduzeća objavljenih u registru godišnjih financijskih izvještaja koji vodi Financijska agencija. ${ }^{6}$ Za obradu podataka korišten je programski paket R.

4 Odluka o donošenju Smjernica politike državnih potpora za razdoblje 2014-2016. Narodne novine, $130 / 13$.

5 Iz Godišnjeg izvješća o državnim potporama za 2015. godinu. Dostupno na http://www. mfin.hr/adminmax/docs/Godisnje\%20izvješće\%20o\%20državnim\%20potporama\%202015..pdf

6 http://www.fina.hr/gfi 
Podaci korišteni u analizi imaju dvodimenzionalnu strukturu podataka. Određuju ih dvije dimenzije od kojih je jedna identifikacijska oznaka poduzeća (ID), a druga vremenska - godina financijskog izvještaja (GOD). Budući da regresijska analiza procjenjuje utjecaje prihoda od državnih subvencija (potpora) na financijske rezultate, ključna pomoćna varijabla je oznaka je li poduzeće u promatranom razdoblju dobilo državne potpore ili nije: POTI_F.

U ovom istraživanju analizirani su podaci o svim poduzećima koja u promatranom razdoblju imaju kontinuirano sva godišnja izvješća i ostvaruju poslovne prihode (aktivna poduzeća) i neovisno o godinama u kojima su primila subvencije ili ih uopće nisu primila. Izuzetak su poduzeća koja pripadaju specifičnim skupinama, za koja nije uvjet da imaju kontinuirano izvješća u promatranom razdoblju zbog malog broja poslovnih subjekata tih skupina. Radi se o relativno malom broju poduzeća, samo 28262 poduzeća, od čega 2348 poduzeća u državnom vlasništvu (tablica 1.). Ukupan broj testiranih specifičnih poduzeća je 39 kroz 11 godina (179 opservacija).

Tablica 1 .

\section{DISTRIBUCIJE PODUZEĆA PO OBLIKU VLASNIŠTVA}

\begin{tabular}{|c|c|c|}
\hline Broj poduzeća & Natpisi stupaca & \\
\hline Natpisi redaka & pot & Ukupni zbroj \\
\hline nbp & $\mathbf{2 8 ~ 2 6 2}$ & $\mathbf{2 8 ~ 2 6 2}$ \\
\hline Državno & 2348 & 2348 \\
\hline Privatno & 25914 & 25914 \\
\hline Ukupni zbroj & $\mathbf{2 8 ~ 2 6 2}$ & $\mathbf{2 8 ~ 2 6 2}$ \\
\hline
\end{tabular}

Izvor: rad autorice

Odabrane su dvije glavne nezavisne varijable za koje se procjenjuje utjecaj subvencija na financijske rezultate specifične skupine poduzeća u promatranom razdoblju, a to su prihodi od subvencija (POTPORE.LOG) i udio prihoda od subvencija u ukupnoj aktivi poduzeća (pot.u.aktivi). One predstavljaju dvije glavne inačice svakoga modela.

Odabrane nezavisne varijable u naravi su na neki način vezane uz visinu iznosa subvencija. Može se čak smatrati da se iznos ukupne aktive specifične skupine poduzeća baš i ne mijenja intenzivno i predstavlja samo konstantu koja prezentira veličinu poduzeća, dok je varijabla prihodi od subvencija prilično volatilna i upućuje na dvije stvari: „živi“ li poduzeće od subvencija (visok omjer) ili su subvencije nesignifikantne s obzirom na ukupno ostvareni prihod. 
Upravo zbog toga je ta nezavisna varijabla u analizi kombinirana i s iznosom primljenih subvencija (POTPORE.LOG) i s udjelom subvencija u aktivi promatranih poduzeća (potp.u.aktivi). Primjerice, 100.000 kuna subvencija u apsolutnom iznosu neće imati isti efekt na poduzeće čija je aktiva 100.000.000 kuna kao na poduzeće čija je aktiva 10.000 kuna. Istih tih 100.000 kuna nema isti efekt ako poduzeće ima ukupni prihod 100.000.000 kuna ili ako ima ukupni prihod (uključujući i subvencije) 110.000 kuna, neovisno o veličini aktive. Upravo se stoga iznos subvencija promatra u odnosu na imovinu i u odnosu na aktivnost.

Odabrane zavisne varijable su: dobit/gubitak razdoblja (DOBGUB.LOG), koeficijent obrtaja ukupne imovine (KOEF:OBRT_IMO.w), koeficijent tekuće likvidnosti (KOEF_TEK_LIK.w), novostvorena vrijednost (NOVA_VR.LOG) i zaposleni temeljem sati rada (ZAP_SATI.w).

Zavisne i nezavisne varijable najprije su transformirane ograničavanjem 2 posto netipičnih vrijednosti varijabli na oba repa distribucije: na 1. percentil na donjem repu distribucije te na 99. percentil na gornjem repu distribucije. Ograničavanjem netipičnih vrijednosti na n-ti percentil postiže se bolja prilagodba regresijskih parametara distribuciji i reprezentativnost regresije s obzirom na to da netipične vrijednosti (outlieri) u tom slučaju, čije vrijednosti mogu biti višestruko više od glavnine distribucije, neće utjecati na nagib regresijskog pravca kao što bi to mogao biti slučaj da nisu ograničene. Na sve zavisne i nezavisne varijable izražene u kunskim iznosima primijenjena je logaritamska transformacija:

$$
x . L O G=\left\{\begin{array}{c}
\ln (x) \forall x>0 \\
0 \forall x=0
\end{array}\right.
$$

Na taj način transformirane su sljedeće varijable: „DOBGUB““, „NOVA_VR“, „DOB_X_ZAP“, „POTPORE“ (u kurzivu su nezavisne varijable). Nazivima varijabli dodan je nastavak ,.LOG“. Time se postiže ujednačena osjetljivost modela na čitavom rasponu vrijednosti.

Kao inicijalni selekcijski test za odabir nezavisnih varijabli potencijalnih kandidata za panel regresiju primjenjuje se univarijatna binomna regresija kojom ce se ispitati signifikantnosti pojedinih nezavisnih varijabli na binomnu varijablu dobit ili gubitak. Pri izradi modela provjerit ce se postoje li potencijalni problemi koji mogu uzrokovati korištene varijable u modelu, a koje u tom slučaju narušavaju pretpostavke koje svaki model višestruke regresije mora ispuniti: problem multikolinearnosti regresorskih varijabli (što može rezultirati nerealno visokim p-vrijednostima), problem autokorelacije reziduala, problem heteroskedastičnosti varijance reziduala i sl. Pri modeliranju individualne heterogenosti uvodi se pretpostavka da se pogreška sastoji od dviju komponenti od kojih je jedna svojstvena pojedinom poduzeću i ne mijenja se kroz vrijeme, gdje je $\varepsilon_{i t}$ idiosinkratska pogreš- 
ka neovisna o oba regresora, a $\mu_{i}$ je komponenta individualne pogreške koja može i ne mora biti korelirana s regresorima.

U slučaju da korelacija postoji, procjena parametara $\beta$ bila bi nekonzistentna, zbog čega se uvodi skup novih parametara koji se procjenjuju, a to su upravo $\mu_{i}$ te općeniti parametar $\alpha_{i t}=\alpha_{i}$ za svaki $t$. To su tzv. fiksni efekti.

Pronalaženjem modela linearne panel regresije moći će se ispitati postoji li ovisnost između mjera učinkovitosti poslovanja i primljenih državnih subvencija, je li ona idiosinkratska (fiksni efekti: svojstvena individualnom poduzeću ili vremenskom trenutku održavajući efekte ekonomskog ciklusa na rezultate poslovanja u odnosu na državne subvencije), ili postoji generička ovisnost poslovnih rezultata o visini i kontinuitetu primljenih državnih subvencija, je li ona linearna ili nelinearna (pri čemu će se raditi transformacije varijabli logaritmiranjem ili nekom drugom nelinearnom transformacijom /Prilog 1./). Rezultati modela (procjene i njihovi predznaci, testovi signifikantnosti /p-vrijednosti/, koeficijent determinacije $/ \mathrm{R}^{2} /$, korigirani koeficijent determinacije /Adjusted $\mathrm{R} /{ }^{7}$, procijenjene standardne devijacije regresije /Std. Error of Estimate/) odgovorit će jesu li poticaji i poslovni rezultati signifikantno pozitivno ili negativno korelirani. Dakle, univarijatnom analizom evaluiraju se sve potencijalne varijable odnosno ispituje se utjecaj svake nezavisne varijable na zavisnu, dok se multivarijatnom analizom utvrđuje razina statističke povezanosti utjecaja subvencija na financijske rezultate specifične skupine poduzeća na nebalansiranom panelu.

\section{Tablica 2 .}

SAŽETAK GLAVNIH VARIJABLI MODELA I NJIHOV UTJECAJ NA ZAVISNE VARIJABLE

\begin{tabular}{|c|c|c|c|c|c|c|c|c|c|c|c|c|}
\hline & $\begin{array}{c}\text { Zavisna } \\
\text { varijabla }\end{array}$ & Values & & & & & & & & \\
\hline & & & \multicolumn{2}{|c|}{$\begin{array}{c}\text { KOEF_OBRT_ } \\
\text { IMO.w }\end{array}$} & \multicolumn{2}{|c|}{$\begin{array}{l}\text { KOEF_TEK_ } \\
\text { LIK.w }\end{array}$} & \multicolumn{2}{|c|}{ ZAP_SATI.w } & \multicolumn{2}{|c|}{$\begin{array}{l}\text { DOBGUB. } \\
\text { LOG }\end{array}$} & \multicolumn{2}{|c|}{ NOVA_VR.LOG } \\
\hline NKD & iter. & Nezavisna varijabla & est. & Rel. utj. & est. & $\begin{array}{l}\text { Rel. } \\
\text { utj. }\end{array}$ & est. & Rel. utj. & est. & $\begin{array}{l}\text { Rel. } \\
\text { utj. }\end{array}$ & est. & $\begin{array}{l}\text { Rel. } \\
\text { utj. }\end{array}$ \\
\hline \multirow[t]{4}{*}{ Državno } & 1 & POTPORE.LOG & $-0,088$ & $3,0 \%$ & $-0,696$ & $10,6 \%$ & 5,031 & $15,9 \%$ & 0,059 & $0,5 \%$ & 0,256 & $11,9 \%$ \\
\hline & & POTP_U_PRIH.w? & 1,153 & $6,3 \%$ & 8,177 & $18,9 \%$ & $-29,203$ & $11,3 \%$ & $-1,903$ & $3,9 \%$ & $-1,201$ & $7,0 \%$ \\
\hline & 2 & pot.u.aktivi.w & 2,775 & $55,5 \%$ & $-3,890$ & $5,8 \%$ & $-4,870$ & $4,6 \%$ & 0,235 & $0,7 \%$ & $-0,594$ & $1,8 \%$ \\
\hline & & POTP_U_PRIH.w & $-2,247$ & $7,8 \%$ & 8,223 & $18,7 \%$ & 1,614 & $6,7 \%$ & $-1,815$ & $3,4 \%$ & 0,693 & $4,1 \%$ \\
\hline
\end{tabular}

Izvor: rad autorice

\footnotetext{
7 POTP_U_PRIH.w (subvencije u ukupnim prihodima) je pomoćna nezavisna varijabla.
} 
Iz sažetog prikaza utjecaja glavnih varijabli modela na uspješnost poslovanja državnih poduzeća može se zaključiti da je relativni utjecaj nezavisne varijable subvencije u aktivi (pot.u.aktivi.w - drugi model) najizraženiji na zavisnu varijablu koeficijent obrtaja imovine (55,5 posto), dok je relativni utjecaj nezavisne varijable prihodi od subvencija (POTPORE.LOG) najizraženiji na zavisnu varijablu broj zaposlenih temeljem sati rada (ZAP_SATI.w). Ujedno prihodi od subvencija imaju relativno visok utjecaj i na novostvorenu vrijednost (11,9 posto) i koeficijent tekuće likvidnosti (10,6 posto).

\section{USPJEŠNOST POSLOVANJA SPECIFIČNE SKUPINE JAVNIH PODUZEĆA U REPUBLICI HRVATSKOJ}

Prema podacima Financijske agencije u razdoblju od 2005. do 2015. godine, najviše subvencija primila su poduzeća u vlasništvu države iz djelatnosti prijevoza (željeznice), prerađivačke industrije (brodogradilišta) i nekretnina (tu je registriran i Zagrebački holding).

Apsolutno najviši iznos subvencija primio je željeznički promet, slijede operateri autocesta, zagrebački gradski prijevoz, vodeni prijevoz te zračni prijevoz. Od ukupno 82 milijarde kuna subvencija 40 posto isplaćeno je sektoru prijevoza i skladišta, a glavninu su dobila javna poduzeća Hrvatske željeznice, Jadrolinija i Croatia Airlines.

U promatranom razdoblju prerađivačka djelatnost doživjela je strukturne promjene. Subvencije su uglavnom primala poduzeća u privatnom vlasništvu premda kroz promatrano razdoblje nije uvijek bilo tako jer od gotovo 9 milijardi kuna primljenih subvencija, 3,3 milijarde kuna primila su brodogradilišta. Građevinski sektor primio je također oko 9 milijardi kuna subvencija, ali zato što su u toj djelatnosti registrirani i hrvatski operateri te autoceste koje su primile gotovo 90 posto subvencija ovoga sektora. U djelatnosti nekretnina registriran je i Zagrebački holding koji subvencije ne prima iz državne blagajne već iz proračuna Grada Zagreba za koji je izdvojeno oko 6 milijardi kuna gdje je najveći korisnik subvencija Zagrebački električni tramvaj.

Kada se subvencije promatraju na ovaj način, onda je vidljivo da je više od polovice ukupnog iznosa od 82 milijarde kuna subvencija utrošeno u subvencioniranje poduzeća koja se na neki način bave prijevozom (a ne proizvodnjom) i koja su svojevrsni monopoli u vlasništvu države ili jedinica regionalne i lokalne samouprave. 
Postoji još jedan problem. Primjerice, samo u 2014. godini od ukupno 5,5 milijardi kuna subvencija, 71 posto $^{8}$ je isplaćeno poduzećima u potpunom ili djelomičnom državnom vlasništvu. Iz toga proizlazi da država pretjerano podupire javna poduzeća, ali ne radi poboljšanja usluga javnih poduzeća već iz političkih razloga, odnosno odgode neminovnog restrukturiranja tih poduzeća koja sa sobom nose niz bolnih rezova.

\subsection{Prikaz rezultata modela jednostavne linearne regresije}

Modeli korišteni u analizi definirani su kao jednadžba pravca s jednom neovisnom varijablom: $\mathrm{y} \sim \mathrm{x}$, gdje y predstavlja zavisne varijable, a x nezavisne varijable iz popisa varijabli, zavisne varijable kandidati za regresiju isključujući trenutačno ispitivanu zavisnu varijablu i one nezavisne varijable koje su visoko korelirane s ispitivanom zavisnom varijablom (koeficijent korelacije $>60 \%$ ).

Analizirani su podaci o poduzećima koja su primila subvencije u godinama kada su primila subvencije OLS: Nebalansirani panel - poticani kako bi se utvrdilo jesu li poticaji (u svojem apsolutnom ili relativnom iznosu) imali značajnijih trenutačnih efekata na rezultate poslovanja u godinama kada su poticaji bili isplaćeni. To se dokazuje ANOVA testom, odnosno analizom utjecaja faktora na varijacije zavisne varijable - odabranih pokazatelja uspješnosti poslovanja. Može biti jednofaktorska ANOVA - kada se mjeri utjecaj jednog faktora (npr.: pripadnost specifičnoj skupini poduzeća) na varijancu promatrane varijable (poslovnog rezultata) ili dvofaktorska ANOVA kada se promatra utjecaj dvaju faktora na varijancu zavisne varijable (npr.: pripadnost specifičnoj skupini poduzeća i oznaka jesu li dobili subvencije ili ne). Ako ANOVA test pokaže da postoji signifikantna ovisnost poslovnog rezultata o pripadnosti specifičnim skupinama i subvencijama, tada se primjenjuje i Tukeyev test.

U nastavku su prikazi odabranih rezultata jednostavnih linearnih modela nezavisnih varijabli prihodi od subvencija (POTPORE.LOG) i udio prihoda od subvencija u ukupnoj aktivi poduzeća (pot.u.aktivi.w) za specifičnu skupinu poduzeća.

8 Iz Godišnjeg izvješća o državnim potporama za 2015. godinu. Dostupno na: http://www. mfin.hr/adminmax/docs/Godisnje\%20izvješće\%20o\%20državnim\%20potporama\%202015..pdf 
A. BUNETA: Utjecaj subvencija na uspješnost poslovanja specifične skupine hrvatskih javnih poduzeća EKONOMSKI PREGLED, 72 (3) 377-412 (2021)

Slika 1 .

\section{PRIKAZ JEDNOSTAVNOG LINEARNOG MODELA ZA ZAVISNU VARIJABLU DOBIT/GUBITAK RAZDOBLJA (DOBGUB.LOG) I NEZAVISNU VARIJABLU POTPORE.LOG}

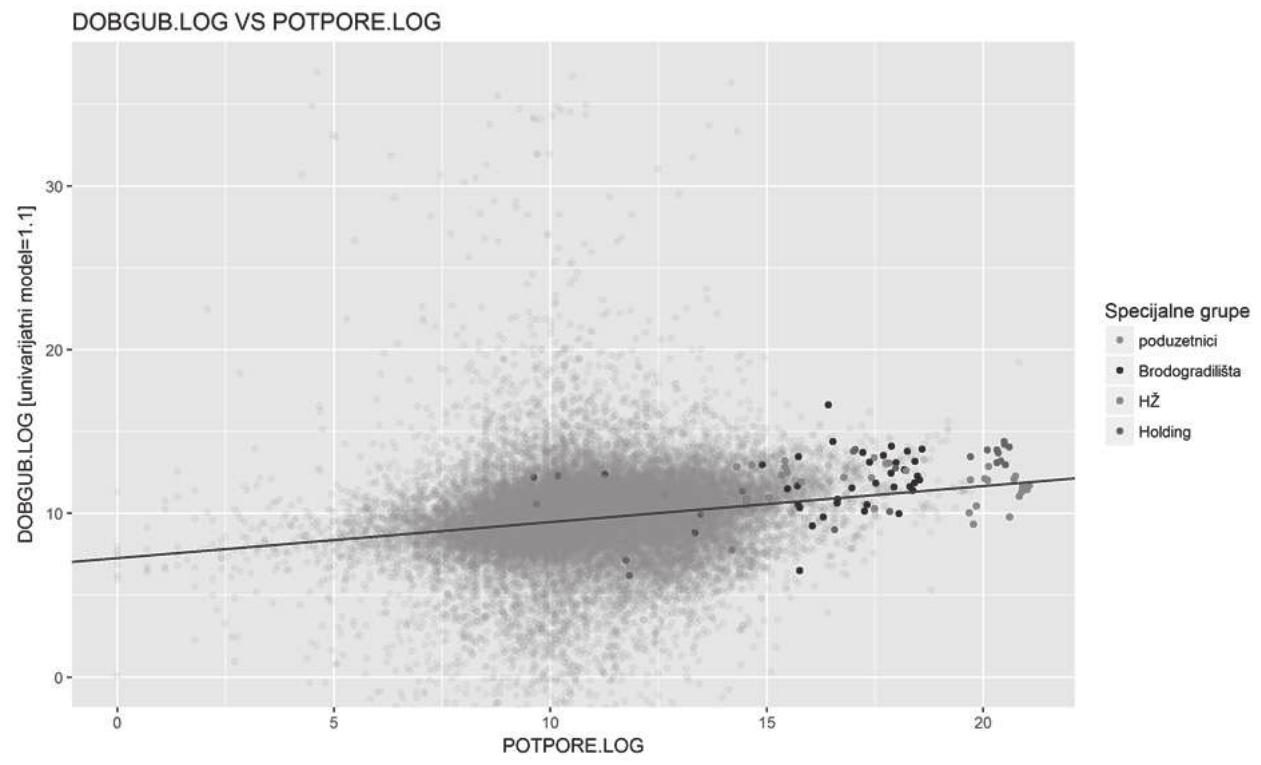

Izvor: rad autorice

Slika 1. prikazuje jednostavni linearni model zavisne varijable dobit/gubitak razdoblja i nezavisne varijable prihodi od subvencije (POTPORE.LOG). Linija na grafikonu predstavlja modelsku procjenu zavisne varijable (DOBGUB.LOG) pomoću univarijatnog modela za nezavisnu varijablu logaritma iznosa potpora (POTPORE.LOG). Na primjeru zavisne varijable DOBGUB.LOG vidljivo je da specifične skupine poduzeća ostvaruju uglavnom veću dobit od modelske procjene temeljene samo na logaritmu iznosa subvencija (POTPORE.LOG), što znači da one ostvaruju i relativno veću dobit u odnosu na dobivene subvencije od ostalih poduzeća u uzorku.

Distribucije DOBGUB.LOG u ovisnosti o pripadnosti specifičnim skupinama i dobivenim subvencijama prikazane su Box-plot dijagramom na sljedećim slikama. 
Slika 2.

BOX-PLOT DISTRIBUCIJE ZA VARIJABLU DOBIT/GUBITAK RAZDOBLJA (DOBGUB.LOG) PREMA SPECIFIČNIM SKUPINAMA I SUBVENCIJAMA

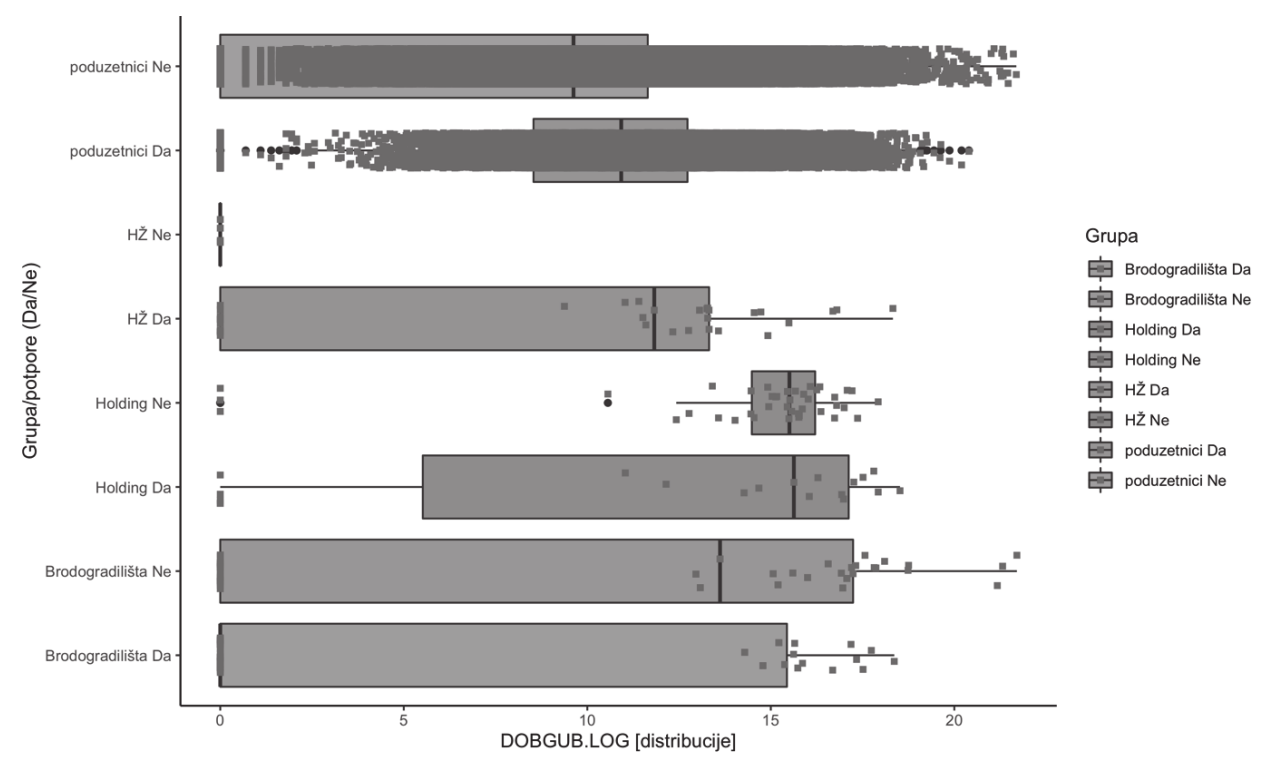

Izvor: rad autorice

Iz prikazanih distribucija za varijablu dobit/gubitak razdoblja vidljivo je da postoje signifikantne razlike poslovnog rezultata u ovisnosti o pripadnosti specifičnim skupinama i subvencijama. Prednjače brodogradilišta, slijedi HŽ te Holding. 
Slika 3 .

\section{BOX-PLOT DISTRIBUCIJE VARIJABLE DOBGUB.LOG PREMA SPECIFIČNOJ SKUPINI}

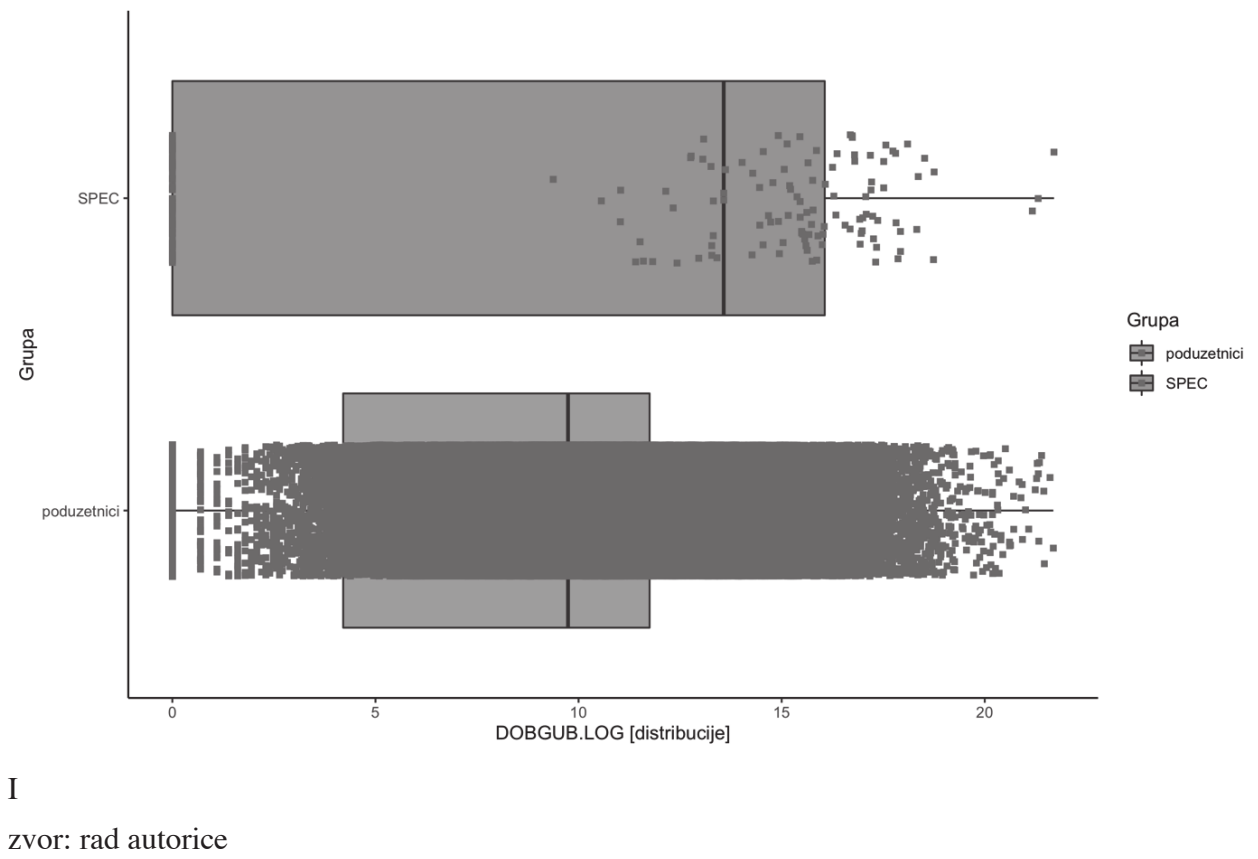

Isto tako iz prikazanih distribucija za varijablu dobit/gubitak razdoblja specifične skupine poduzeća u odnosu na ostala poduzeća vidljivo je da postoje signifikantne razlike poslovnoga rezultata između specifične skupine poduzeća i ostalih poduzeća, te da većina specifičnih poduzeća ostvaruje bolje rezultate.

Utječu li subvencije i pripadnost specifičnoj skupini poduzeća na poslovni rezultat potvrđuje se ANOVA testom. U testu se rabi F distribucija, a kao kritična vrijednost uzeta je razina signifikantnosti 5 posto. Empirijske vrijednosti F-testa uspoređuju se s kritičnim vrijednostima $F 5$ posto, a ocjena signifikantnosti provodi se pomoću p-vrijednosti: empirijska p-vrijednost $<$ kritične p-vrijednosti 5 posto dokazuje se značajan utjecaj pripadnosti specifičnoj skupini i dodijeljenih subvencija na poslovni rezultat.

Sljedeća tablica prikazuje rezultate ANOVA analize pomoću F-distribucije. 
Tablica 3 .

\section{REZULTATI ANOVA ANALIZE POMOĆU F-DISTRIBUCIJE}

\begin{tabular}{|c|c|l|l|c|r|r|r|c|}
\hline $\begin{array}{c}\text { \# zav. } \\
\text { var. }\end{array}$ & $\begin{array}{c}\text { \# } \\
\text { grupiranja }\end{array}$ & \multicolumn{1}{|c|}{ formula } & $\begin{array}{c}\text { izvor } \\
\text { varijacije }\end{array}$ & Df & \multicolumn{1}{|c|}{ Sum Sq } & Mean Sq & $\begin{array}{c}\text { F } \\
\text { value }\end{array}$ & $\operatorname{Pr}(>\mathrm{F})$ \\
\hline 1 & 1 & DOBGUB.LOG $\sim$ SPEC_BP & between & \multicolumn{1}{c|}{7} & $83.531,99$ & $11.933,14$ & 471,61 & 0 \\
\hline 1 & 1 & DOBGUB.LOG $\sim$ SPEC_BP & within & 338501 & $8.565 .159,41$ & 25,30 & & \\
\hline 1 & 2 & DOBGUB.LOG $\sim$ SPEC_G & between & 1 & 492,36 & 492,36 & 19,27 & $1,13 \mathrm{E}-05$ \\
\hline 1 & 2 & DOBGUB.LOG $\sim$ SPEC_G & within & 338507 & $8.648 .199,04$ & 25,55 & & \\
\hline
\end{tabular}

Izvor: rad autorice

U prvom testu korišten je faktor SPEC_BP koji prikazuje pripadnost skupini i korištenje subvencija (odgovara gornjoj slici box-plot distribucije), a u drugom testu korišten je faktor pripadnosti specifičnoj skupini, neovisno o korištenju subvencija.

Turkeyevim testom dokazuje se koje su dvije aritmetičke sredine signifikantno različite $\mathrm{s}$ obzirom na korištene faktore.

Tablica 4.

PRIKAZ REZULTATA TURKEYEVIM TESTOM

\begin{tabular}{|c|c|l|l|r|r|r|}
\hline $\begin{array}{c}\text { \# zav. } \\
\text { var. }\end{array}$ & $\begin{array}{c}\text { \# } \\
\text { grupiranja }\end{array}$ & \multicolumn{1}{|c|}{ formula } & \multicolumn{1}{|c|}{ par } & diff & 1 wr & upr \\
\hline 1 & 1 & DOBGUB.LOG $\sim$ SPEC_BP & Brodogradilišta Ne-Brodogradilišta Da & 3,92 & 0,53 & 7,31 \\
\hline 1 & 1 & DOBGUB.LOG $\sim$ SPEC_BP & Holding Da-Brodogradilišta Da & 6,05 & 1,81 & 10,30 \\
\hline 1 & 1 & DOBGUB.LOG $\sim$ SPEC_BP & Holding Ne-Brodogradilišta Da & 8,62 & 5,26 & 11,99 \\
\hline 1 & 1 & DOBGUB.LOG $\sim$ SPEC_BP & HŽ Da-Brodogradilišta Da & 3,30 & $-0,29$ & 6,88 \\
\hline 1 & 1 & DOBGUB.LOG $\sim$ SPEC_BP & HŽ Ne-Brodogradilǐsta Da & $-5,68$ & $-13,68$ & 2,31 \\
\hline 1 & 1 & DOBGUB.LOG $\sim$ SPEC_BP & poduzetnici Da-Brodogradilišta Da & 4,01 & 1,60 & 6,42 \\
\hline 1 & 1 & DOBGUB.LOG $\sim$ SPEC_BP & poduzetnici Ne-Brodogradilišta Da & 2,24 & $-0,17$ & 4,65 \\
\hline 1 & 1 & DOBGUB.LOG $\sim$ SPEC_BP & Holding Da-Brodogradilišta Ne & 2,13 & $-2,10$ & 6,36 \\
\hline 1 & 1 & DOBGUB.LOG $\sim$ SPEC_BP & Holding Ne-Brodogradilišta Ne & 4,70 & 1,36 & 8,05 \\
\hline 1 & 1 & DOBGUB.LOG $\sim$ SPEC_BP & HŽ Da-Brodogradilišta Ne & $-0,62$ & $-4,19$ & 2,94 \\
\hline 1 & 1 & DOBGUB.LOG $\sim$ SPEC_BP & HŽ Ne-Brodogradilišta Ne & $-9,61$ & $-17,59$ & $-1,62$ \\
\hline 1 & 1 & DOBGUB.LOG $\sim$ SPEC_BP & poduzetnici Da-Brodogradilǐ̌ta Ne & 0,09 & $-2,30$ & 2,47 \\
\hline
\end{tabular}


A. BUNETA: Utjecaj subvencija na uspješnost poslovanja specifične skupine hrvatskih javnih poduzeća EKONOMSKI PREGLED, 72 (3) 377-412 (2021)

\begin{tabular}{|c|c|c|c|c|c|c|}
\hline $\begin{array}{c}\text { \# zav. } \\
\text { var. }\end{array}$ & $\begin{array}{c}\# \\
\text { grupiranja }\end{array}$ & formula & par & diff & lwr & upr \\
\hline 1 & 1 & DOBGUB.LOG SPEC_BP & poduzetnici Ne-Brodogradilišta $\mathrm{Ne}$ & $-1,68$ & $-4,06$ & 0,70 \\
\hline 1 & 1 & DOBGUB.LOG SPEC_BP & Holding Ne-Holding Da & 2,57 & $-1,64$ & 6,79 \\
\hline 1 & 1 & DOBGUB.LOG $\sim$ SPEC_BP & HŽ Da-Holding Da & $-2,76$ & $-7,15$ & 1,63 \\
\hline 1 & 1 & DOBGUB.LOG SPEC_BP & HŽ Ne-Holding Da & $-11,74$ & $-20,13$ & $-3,35$ \\
\hline 1 & 1 & DOBGUB.LOG SPEC_BP & poduzetnici Da-Holding Da & $-2,05$ & $-5,55$ & 1,45 \\
\hline 1 & 1 & DOBGUB.LOG SPEC_BP & poduzetnici Ne-Holding $\mathrm{Da}$ & $-3,82$ & $-7,31$ & $-0,32$ \\
\hline 1 & 1 & DOBGUB.LOG SPEC_BP & HŽ Da-Holding Ne & $-5,33$ & $-8,87$ & $-1,78$ \\
\hline 1 & 1 & DOBGUB.LOG SPEC_BP & HŽ Ne-Holding Ne & $-14,31$ & $-22,29$ & $-6,33$ \\
\hline 1 & 1 & DOBGUB.LOG SPEC_BP & poduzetnici Da-Holding $\mathrm{Ne}$ & $-4,62$ & $-6,97$ & $-2,26$ \\
\hline 1 & 1 & DOBGUB.LOG SPEC_BP & poduzetnici Ne-Holding $\mathrm{Ne}$ & $-6,39$ & $-8,74$ & $-4,03$ \\
\hline 1 & 1 & DOBGUB.LOG SPEC_BP & HŽ Ne-HŽ Da & $-8,98$ & $-17,05$ & $-0,91$ \\
\hline 1 & 1 & DOBGUB.LOG SPEC_BP & poduzetnici Da-HŽ Da & 0,71 & $-1,95$ & 3,36 \\
\hline 1 & 1 & DOBGUB.LOG SPEC_BP & poduzetnici Ne-HŽ Da & $-1,06$ & $-3,71$ & 1,59 \\
\hline 1 & 1 & DOBGUB.LOG $\sim$ SPEC_BP & poduzetnici Da-HŽ Ne & 9,69 & 2,07 & 17,31 \\
\hline 1 & 1 & DOBGUB.LOG SPEC_BP & poduzetnici $\mathrm{Ne}-\mathrm{HŽ} \mathrm{Ne}$ & 7,92 & 0,30 & 15,55 \\
\hline 1 & 1 & DOBGUB.LOG SPEC_BP & poduzetnici Ne-poduzetnici Da & $-1,77$ & $-1,86$ & $-1,67$ \\
\hline 1 & 2 & DOBGUB.LOG $\sim$ SPEC_G & SPEC-poduzetnici & 1,66 & 0,92 & 2,40 \\
\hline
\end{tabular}

Izvor: rad autorice

Iz tablice je vidljivo da specifične skupine u cjelini i poduzeća imaju signifikantno različite aritmetičke sredine DOBGUB.LOG. Jednako se tako signifikantno razlikuju poslovni rezultati poduzeća sa subvencijama u odnosu na subvencionirana brodogradilišta, dok se rezultati poduzeća sa subvencijama ne razlikuju značajno (na razini 5 posto značajnosti) od poslovnih rezultata Holdinga i HŽ-a s potporama. Međutim, subvencije značajno utječu na poslovne rezultate kako poduzeća tako i HŽ-a i brodogradilišta, dok potpore dodijeljene Holdingu nisu imale značajniji utjecaj na DOBGUB.LOG.

Drugi model pokazuje odnos koeficijenta tekuće likvidnosti specifične skupine poduzeća u odnosu na modelsku procjenu. 
Slika 4.

\section{PRIKAZ JEDNOSTAVNOG LINEARNOG MODELA ZA ZAVISNU VARIJABLU KOEFICIJENT TEKUĆE LIKVIDNOSTI (KOEF_TEK_LIK.W) I NEZAVISNU VARIJABLU POTPORE.LOG}

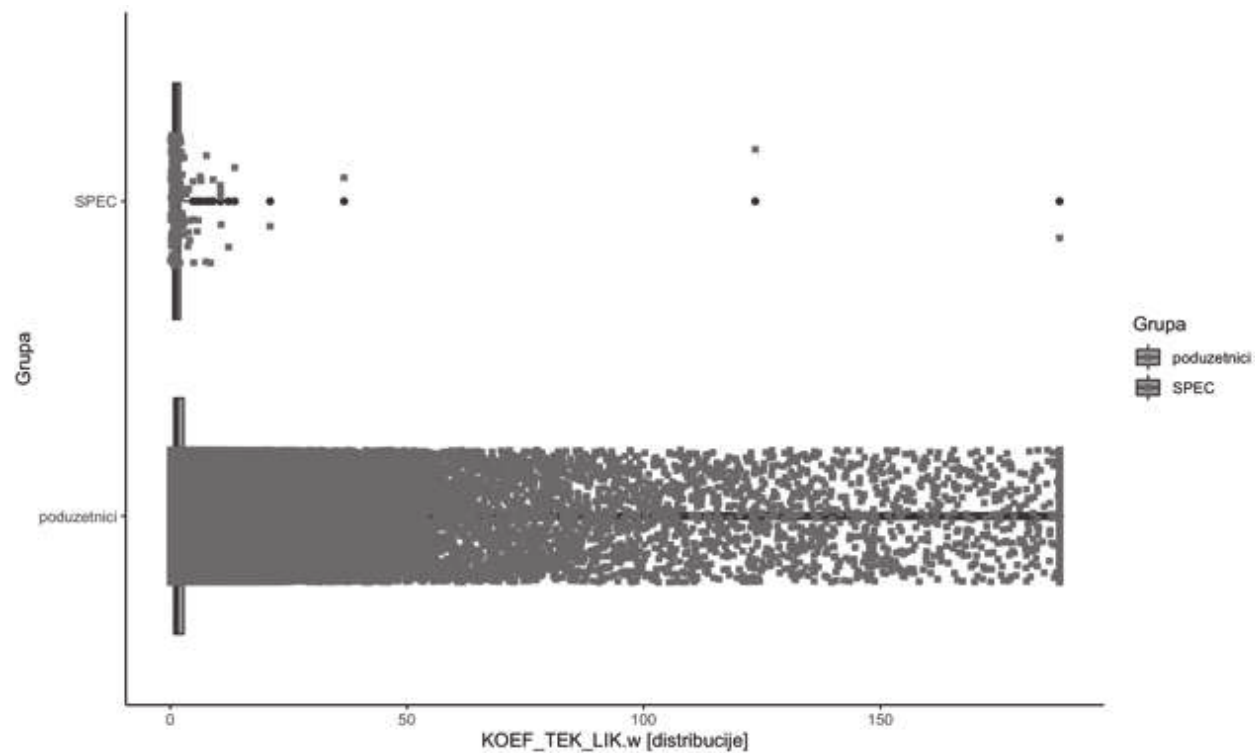

Izvor: rad autorice

Slika 5. prikazuje jednostavni linearni model zavisne varijable koeficijent tekuće likvidnosti (KOEF_TEK_LIK.w) i nezavisne varijable prihodi od subvencija (POTPORE.LOG). Pokazuje da su specifične skupine poduzeća uglavnom ispod i iznad pravca regresije, što znači da odstupaju od ostalih poduzeća u uzorku. Odnosno, uglavnom ostvaruju manju likvidnost u odnosu na modelsku procjenu temeljenu na logaritmu iznosa subvencija (POTPORE.LOG).

Navedeno upućuje na zaključak da su subvencije uglavnom tražila i dobivala specifična poduzeća slabije likvidnosti što implicira na veliku ovisnost njihova poslovanja o državnim subvencijama.

Slijede Box-plot dijagrami distribucija varijable koeficijent tekuće likvidnosti u ovisnosti o pripadnosti specifičnim skupinama i dobivenim subvencijama. 
A. BUNETA: Utjecaj subvencija na uspješnost poslovanja specifične skupine hrvatskih javnih poduzeća EKONOMSKI PREGLED, 72 (3) 377-412 (2021)

Slika 5 .

\section{BOX-PLOT DISTRIBUCIJE ZA VARIJABLU KOEF_TEK_LIK.W PREMA SPECIFIČNIM SKUPINAMA I POTPORAMA}

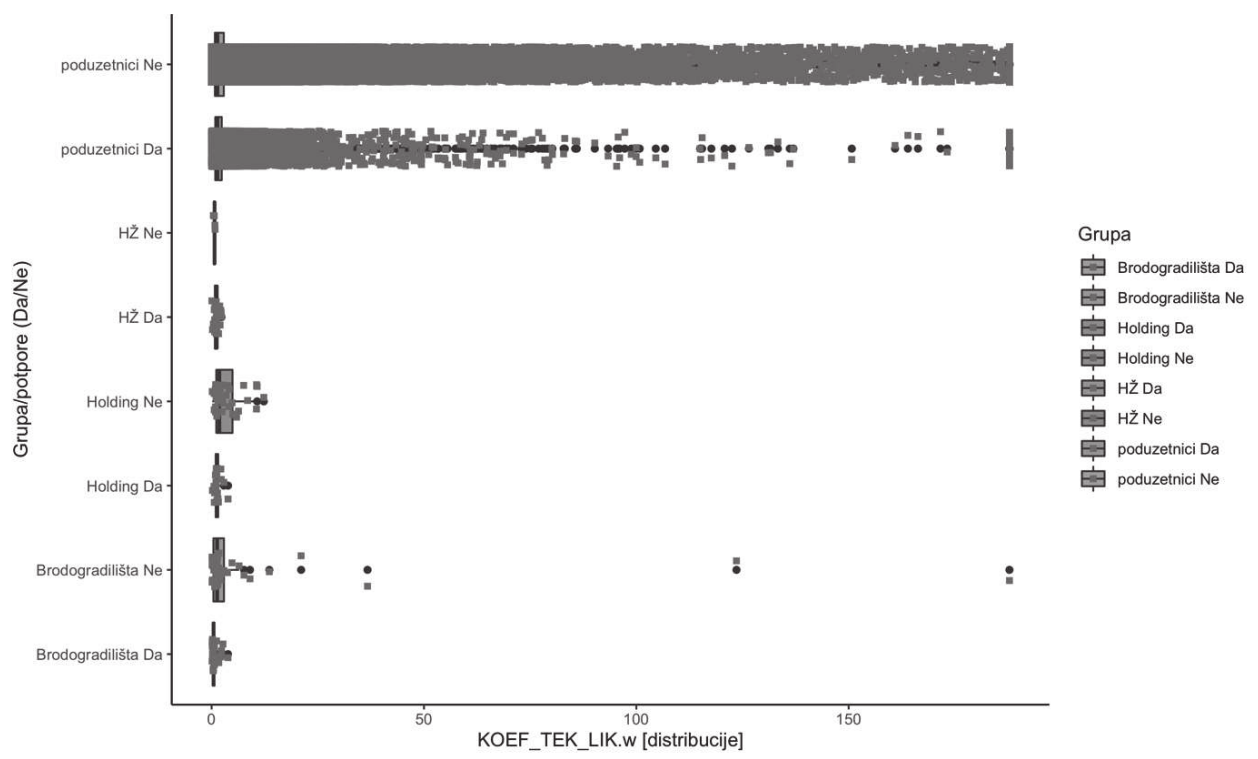

Izvor: rad autorice

Iz prikazanih distribucija za varijablu koeficijent tekuće likvidnosti vidljivo je da postoje vrlo male signifikantne razlike promatranoga koeficijenta u ovisnosti o pripadnosti specifičnim skupinama i subvencijama. Nešto značajniji je Holding. 
Slika 6.

\section{BOX-PLOT DISTRIBUCIJE ZA VARIJABLU KOEF_TEK_LIK.W PREMA SPECIFIČNOJ SKUPINI}

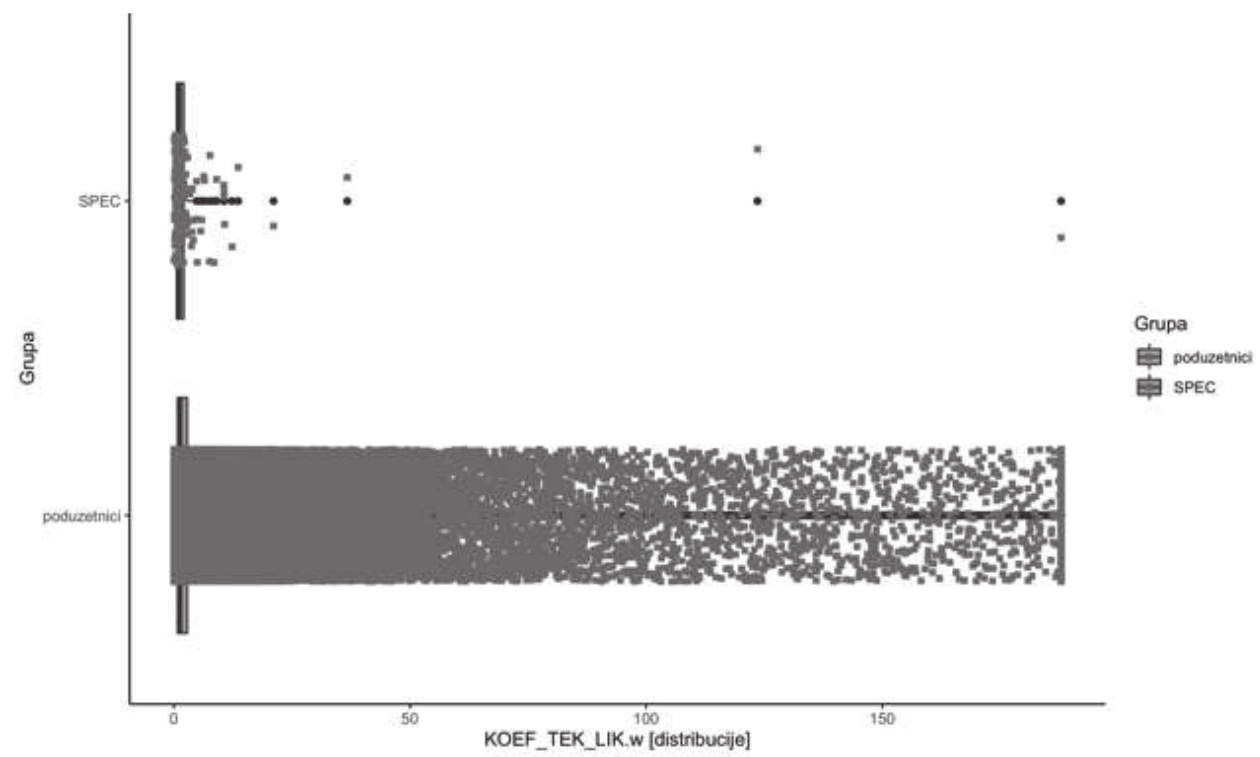

Izvor: rad autorice

Promatra li se koeficijent tekuće likvidnosti specifične skupine poduzeća u odnosu na ostala poduzeća može se zapaziti da postoji signifikantna razlika. Specifične skupine poduzeća ostvaruju uglavnom vrlo malu likvidnost u odnosu na ostala poduzeća u uzorku iz čega se može zaključiti da su njihova likvidnost, a i ukupno poslovanje izrazito ovisni o državnim subvencijama te da subvencije imaju značajnu ulogu u održavanju njihove likvidnosti.

Slijedi prikaz jednostavnoga linearnog modela druge nezavisne varijable pot.u.aktivi.w u odnosu na modelsku procjenu. 
A. BUNETA: Utjecaj subvencija na uspješnost poslovanja specifične skupine hrvatskih javnih poduzeća EKONOMSKI PREGLED, 72 (3) 377-412 (2021)

Slika 7 .

PRIKAZ JEDNOSTAVNOGA LINEARNOG MODELA ZA ZAVISNU VARIJABLU KOEFICIJENT OBRTAJA IMOVINE (KOEF_OBRT_IMO.W) I NEZAVISNU VARIJABLU POT.U.AKTIVI.W

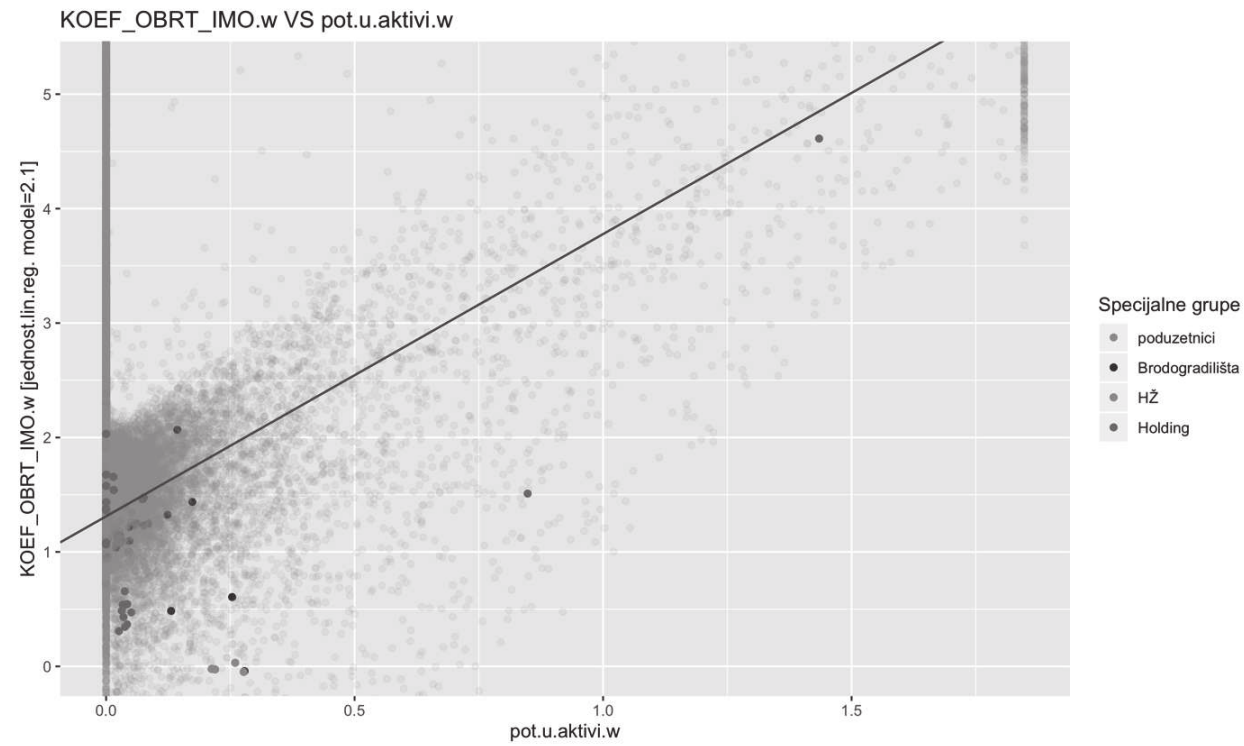

Izvor: rad autorice

Jednostavni linearni model zavisne varijable koeficijent obrtaja imovine (KOEF_OBRT_IMO.w) i nezavisne varijable subvencije u aktivi (pot.u.aktivi.w) pokazuje relativno mali utjecaj jer je koeficijent obrtaja imovine specifične skupine poduzeća manji u odnosu na cijeli model, a što upućuje na zaključak da su ta poduzeća izrazito neefikasna i ovisna o subvencijama.

Za potpuno objektivnu ocjenu trebalo bi uzeti u obzir i gospodarsku djelatnost promatranih poduzeća o kojoj također ovisi vrijednost toga pokazatelja. Uzrok niskoga koeficijenta obrtaja imovine može biti uz neučinkovitost u poslovanju i kapitalno intenzivni karakter poslovanja (Robinson, Van Greuring, Henry i Broihahn, 2009, str. 283). Ocjena o tome je li uzrok niskoga koeficijenta obrtaja imovine kapitalno intenzivna djelatnost ili nedjelotvornost u korištenju imovine može se ispitati usporedbom koeficijenta obrtaja imovine i koeficijenta obrtaja kratkotrajne imovine. 
Osim toga, koeficijente obrtaja imovine cjelokupne industrije potrebno je usporediti i s veličinom poduzeća koja posluju u određenoj gospodarskoj djelatnosti te gospodarskim okruženjem.

Slijede Box-plot dijagrami distribucija varijable koeficijent obrtaja imovine u ovisnosti o pripadnosti specifičnim skupinama i dobivenim subvencijama te prema specifičnoj skupini poduzeća.

Slika 8 .

\section{BOX-PLOT DISTRIBUCIJE ZA VARIJABLU KOEF_OBRT_IMO.W PREMA SPECIFIČNIM SKUPINAMA I POTPORAMA}

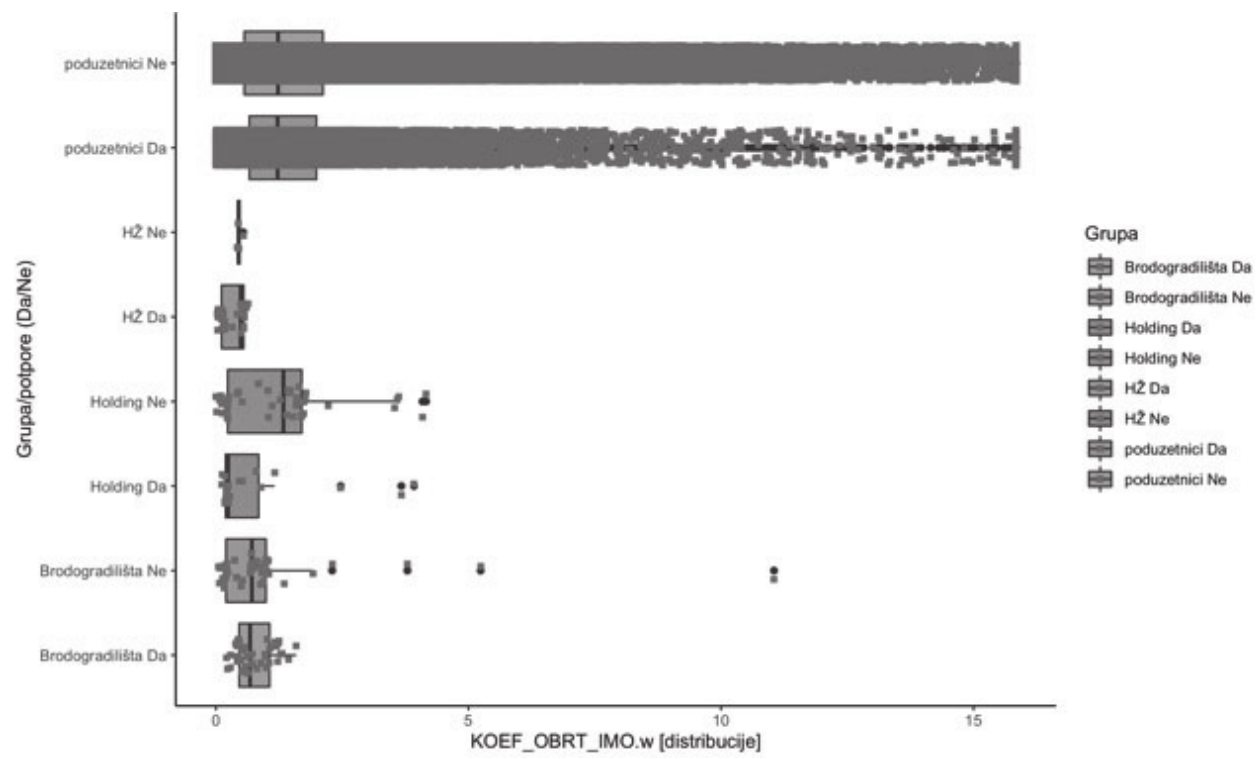

Izvor: rad autorice

Iz prikazanih distribucija (slika 9.) za varijablu koeficijent obrtaja imovine vidljivo je da postoje vrlo male signifikantne razlike promatranoga koeficijenta $\mathrm{u}$ ovisnosti o pripadnosti specifičnim skupinama i subvencijama. Nešto značajnije se izdvajaju Holding i brodogradilišta. 
Slika 9.

\section{BOX-PLOT DISTRIBUCIJE ZA VARIJABLU KOEF_OBRT_IMO.W PREMA SPECIFIČNOJ SKUPINI}

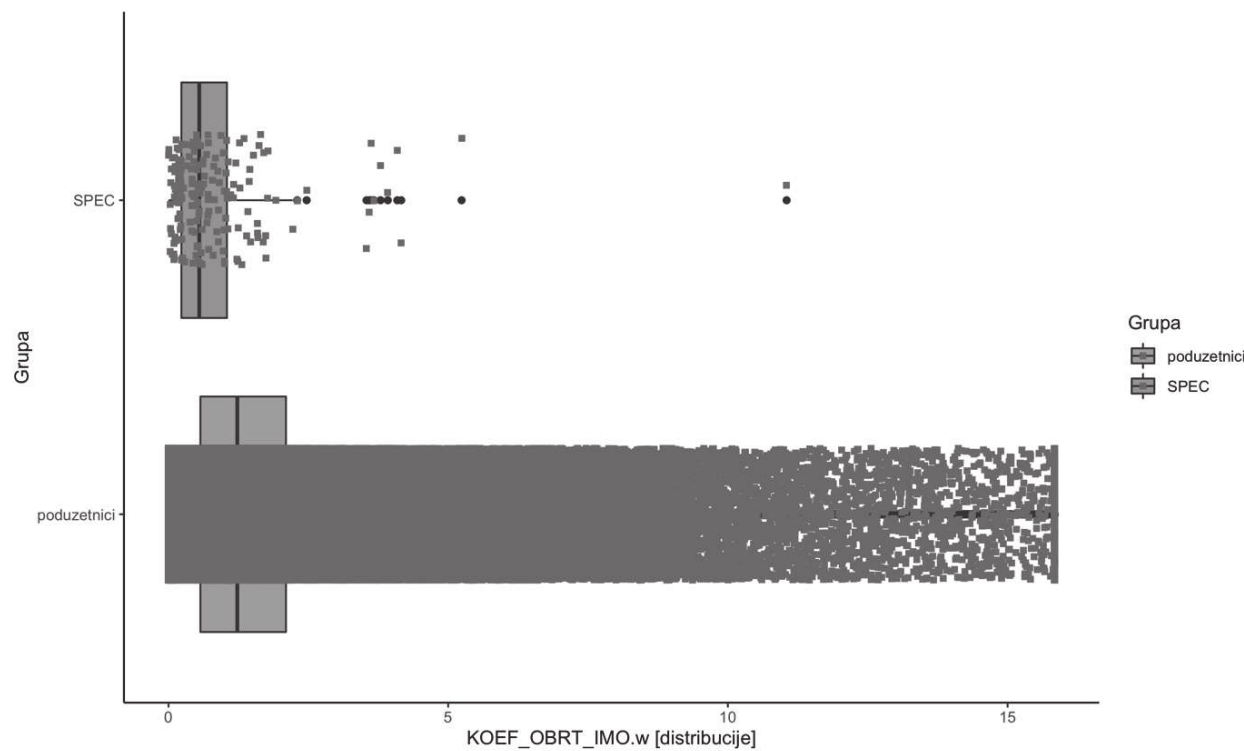

Izvor: rad autorice

Promatra li se koeficijent obrtaja imovine specifične skupine poduzeća u odnosu na ostala poduzeća, može se zapaziti da postoji značajna signifikantna razlika. Specifične skupine poduzeća ostvaruju uglavnom vrlo mali koeficijent obrtaja imovine u odnosu na ostala poduzeća u uzorku, odnosno da su neučinkovita i ovisna o subvencijama.

Sljedeći jednostavni linearni model stavlja u odnos broj zaposlenih temeljem sati rada specifične skupine poduzeća u odnosu na modelsku procjenu. 
Slika 10 .

\section{PRIKAZ JEDNOSTAVNOG LINEARNOG MODELA ZA ZAVISNU VARIJABLU BROJ ZAPOSLENIH TEMELJEM SATI RADA (ZAP_SATI.W) I NEZAVISNU VARIJABLU POTPORE.LOG}

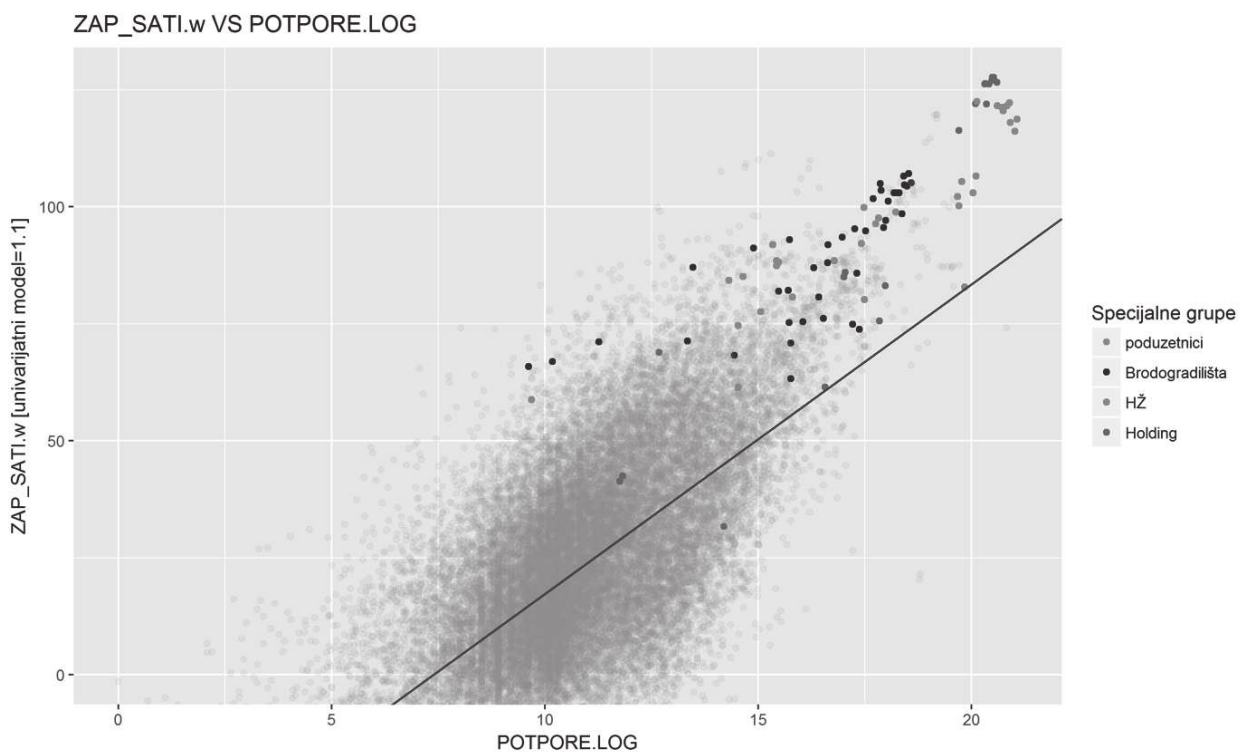

Izvor: rad autorice

Zavisna varijabla ZAP_SATI.w za specifičnu skupinu poduzeća je viša od modelske procjene temeljene samo na logaritmu subvencija (POTPORE.LOG) za sva poduzeća osim jednog, što upućuje na relativno povećano zapošljavanje.

Distribucije varijable broj zaposlenih temeljem stati rada (ZAP_SATI.w) u ovisnosti o pripadnosti specifičnim skupinama i dobivenim subvencijama te samo prema specifičnoj skupini poduzeća prikazane su u nastavku. 
A. BUNETA: Utjecaj subvencija na uspješnost poslovanja specifične skupine hrvatskih javnih poduzeća EKONOMSKI PREGLED, 72 (3) 377-412 (2021)

Slika 11 .

\section{BOX-PLOT DISTRIBUCIJE VARIJABLE ZAP_SATI.W PREMA SPECIFIČNIM SKUPINAMA I POTPORAMA}

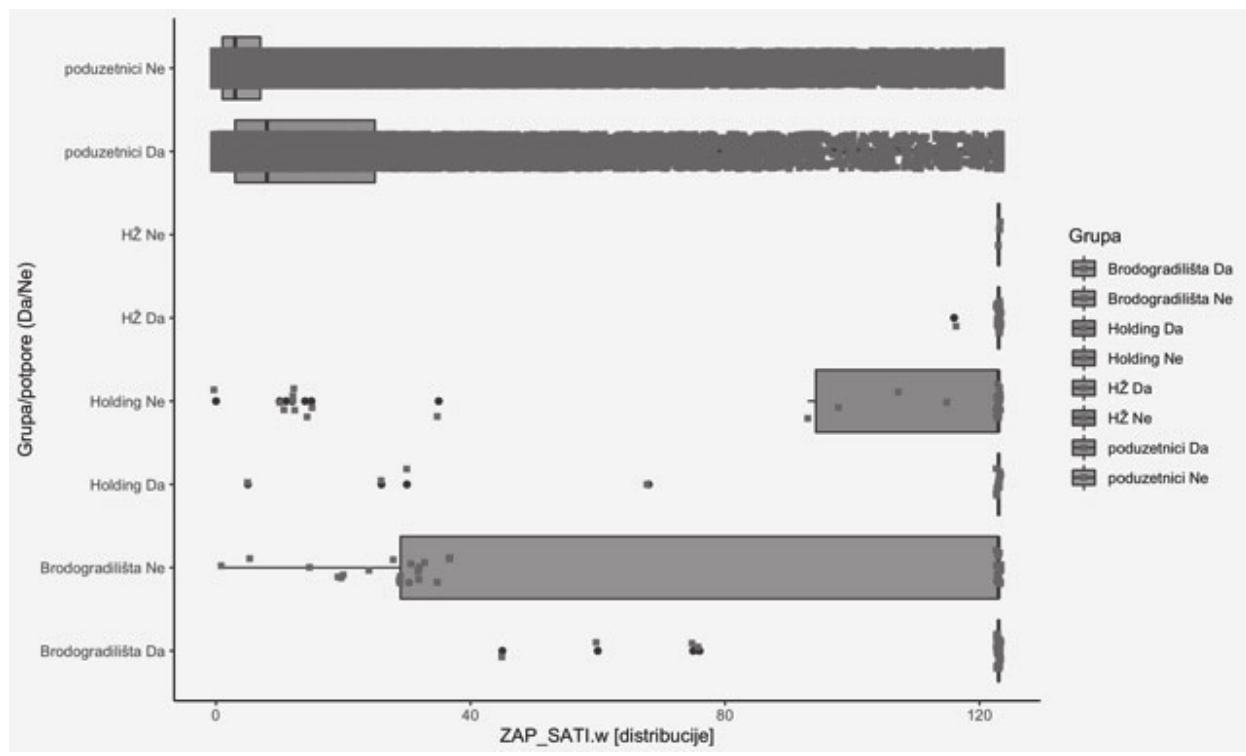

Izvor: rad autorice

Iz prikazanih distribucija za varijablu broj zaposlenih temeljem sati rada može se izvesti zaključak da apsolutni iznosi subvencija i pripadnost specifičnoj skupini poduzeća imaju relativan utjecaj na povećanje broja zaposlenih u tim poduzećima, ali i da su subvencije dobivala poduzeća s većim brojem zaposlenih kao što su brodogradilišta i Holding. 
Slika 12

\section{BOX-PLOT DISTRIBUCIJE VARIJABLE ZAP_SATI.W PREMA SPECIFIČNOJ SKUPINI}

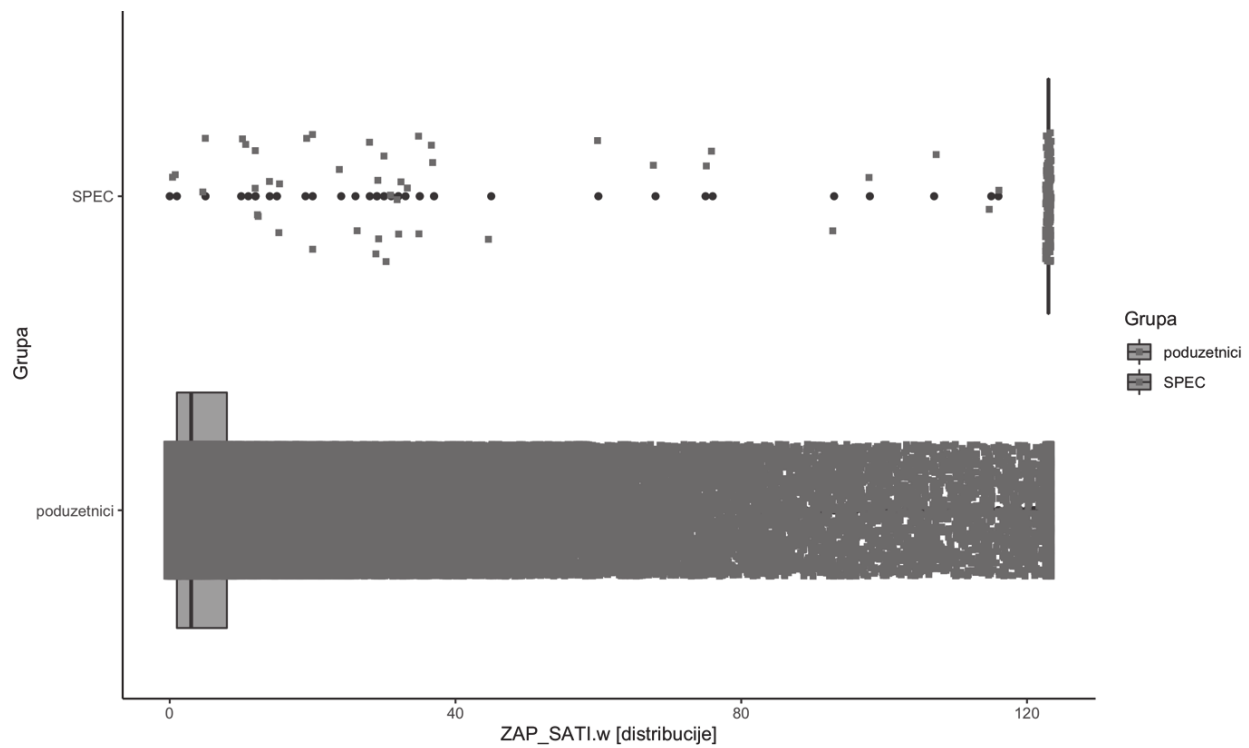

Izvor: rad autorice

Promatraju li se samo distribucije varijable broj zaposlenih temeljem sati rada specifične skupine poduzeća u odnosu na ostala poduzeća, mogu se zapaziti signifikantne razlike. Primljene subvencije imaju relativno mali utjecaj na povećano zapošljavanje u specifičnoj skupini poduzeća u odnosu na ostala poduzeća, ali i da su ih primala specifična poduzeća s većim brojem zaposlenih.

Sljedeći univarijatni model stavlja u odnos novostvorenu vrijednost i prihode od subvencija. 
Slika 13.

\section{PRIKAZ JEDNOSTAVNOG LINEARNOG MODELA ZA ZAVISNU VARIJABLU NOVOSTVORENU VRIJEDNOST (NOVA_VR.LOG) I NEZAVISNU VARIJABLU POTPORE.LOG}

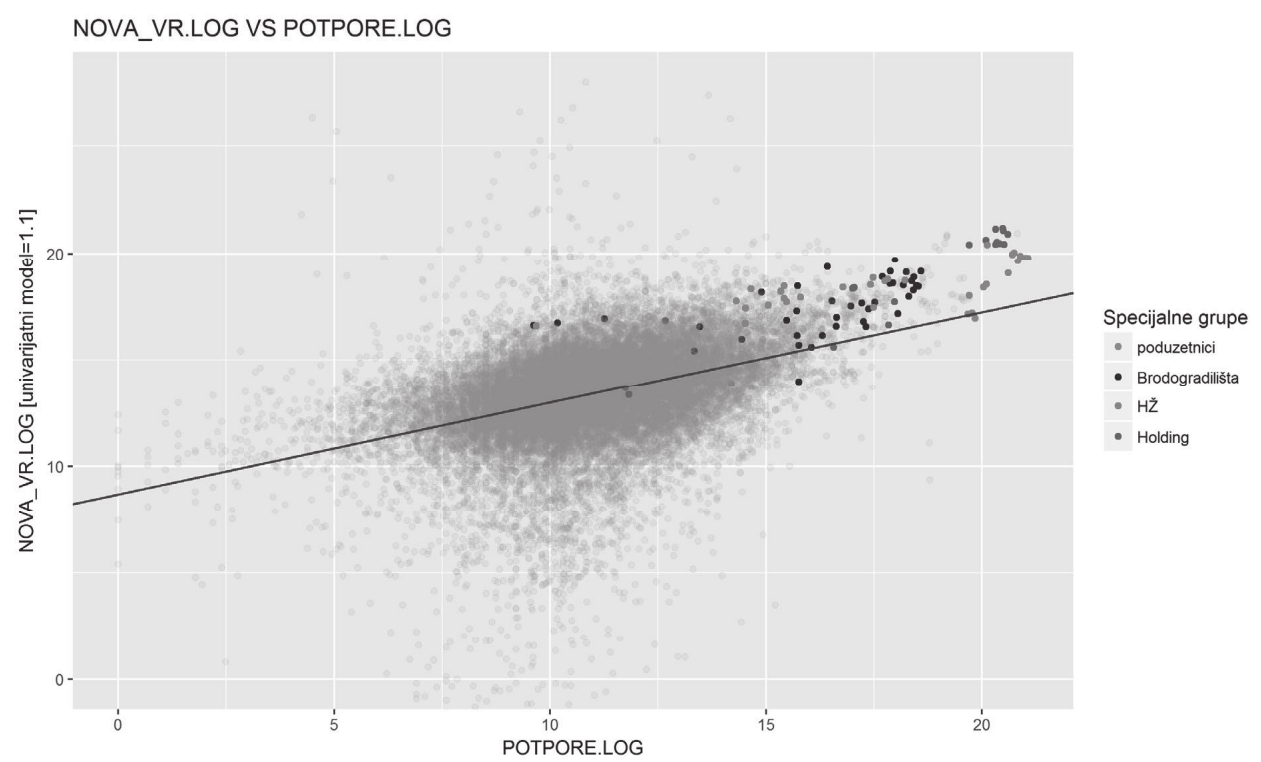

Izvor: rad autorice

Model za zavisnu varijablu novostvorena vrijednost pokazuje da velika većina specifičnih poduzeća ostvaruje veću novostvorenu vrijednost od modelske procjene temeljene samo na logaritmu iznosa subvencija (POTPORE.LOG). Što znači da prihodi od subvencija imaju relativno pozitivan utjecaj na novostvorenu vrijednost tih poduzeća, dok s druge strane s obzirom na njihov relativno visok udio u ukupnim prihodima, imaju negativan utjecaj na njihovo ukupno poslovanje i učinkovitost jer se previše oslanjaju na pomoć države kroz subvencije. 
Slika 14 .

\section{BOG-PLOT DISTRIBUCIJE VARIJABLE NOVA_VR.LOG PREMA SPECIFIČNIM SKUPINAMA I POTPORAMA}

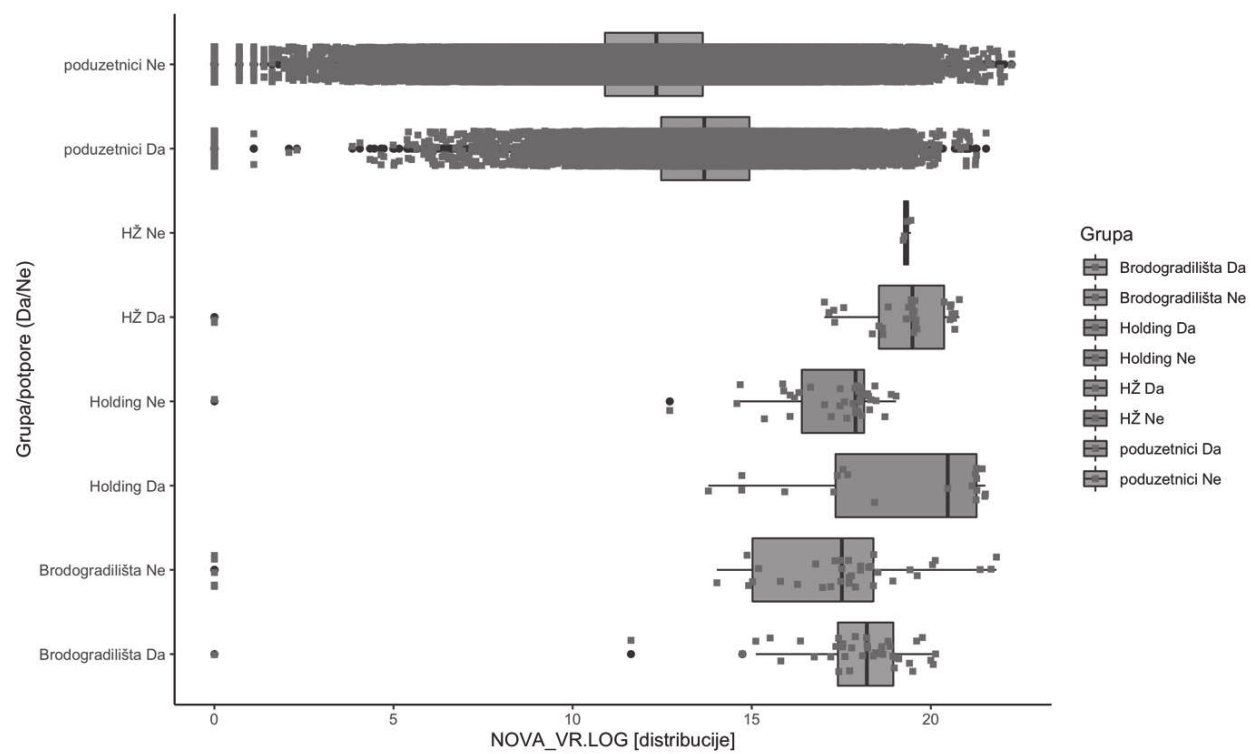

Izvor: rad autorice

Box-plot dijagram distribucija varijable novostvorena vrijednost $\mathrm{u}$ ovisnosti o pripadnosti specifičnim skupinama poduzeća i dobivenim subvencijama pokazuje da postoje signifikantne razlike promatranog pokazatelja u ovisnosti o pripadnosti specifičnim skupinama i subvencijama. Značajnije se izdvajaju Holding, HŽ, pa i brodogradilišta. 
Slika 15.

\section{BOX-PLOT DISTRIBUCIJE VARIJABLE NOVA_VR.LOG PREMA SPECIFIČNOJ SKUPINI}

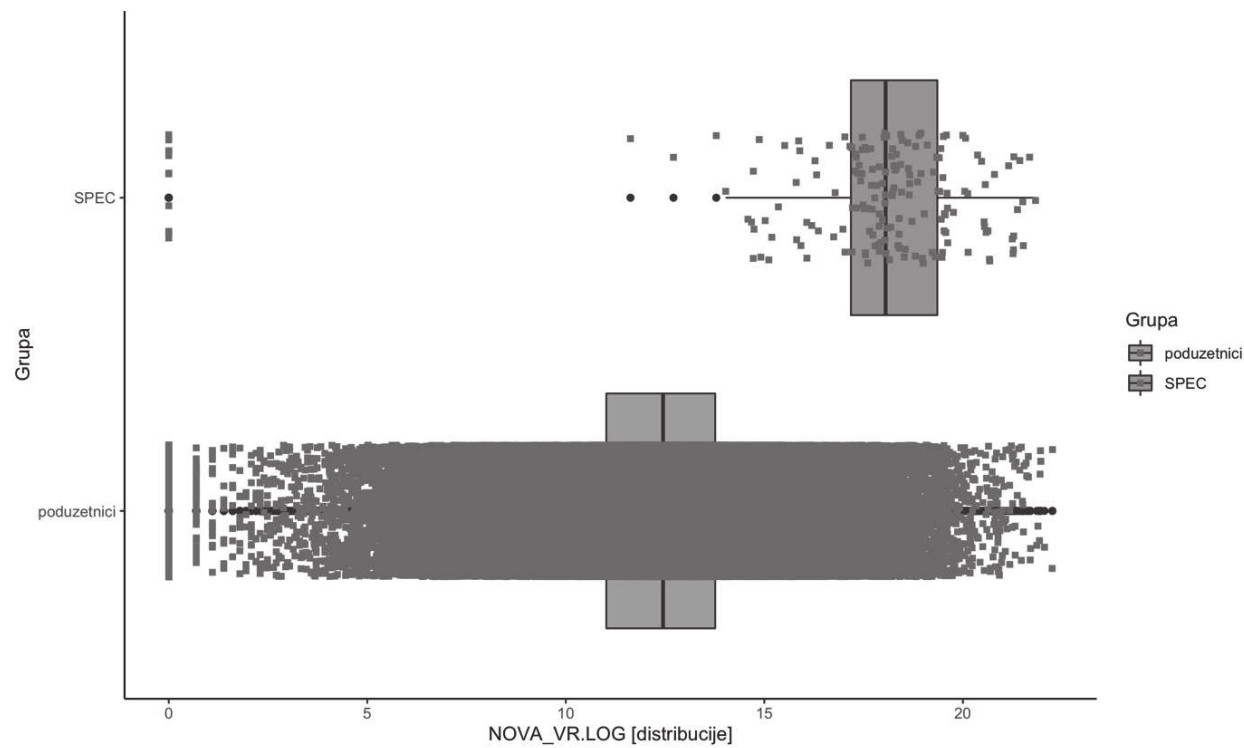

Izvor: rad autorice

Međutim, promatraju li se samo distribucije varijable novostvorena vrijednost specifične skupine poduzeća u odnosu na ostala poduzeća, može se zapaziti da prihodi od subvencija imaju relativno pozitivan i značajan utjecaj na novostvorenu vrijednost specifične skupine poduzeća.

S druge strane relativno visok udio prihoda od subvencija u ukupnim prihodima ima negativan učinak na njihovu ukupnu učinkovitost jer se previše oslanjaju na pomoć države kroz subvencije.

\section{ZAKLJUČAK}

U ovom radu analiziran je utjecaj subvencija na uspješnost poslovanja specifične skupine poduzeća modelima koji imaju najveće ovisnosti zavisnih 
varijabli o nezavisnim na nebalansiranom panelu poduzeća (s primljenim subvencijama).

U ekonomskom smislu i financijski rezultat (dobit/gubitak razdoblja) pokazuje uspješnost poslovanja. Istraživanje je pokazalo da su specifične skupine poduzeća u odnosu na ostala poduzeća korisnike državnih subvencija u promatranom razdoblju upravo zahvaljujući subvencijama ostvarila bolju uspješnost poslovanja od modelske procjene, ali i da im se rezultati poslovanja razlikuju u odnosu na ostala poduzeća u uzorku. Tako se primjerice signifikantno razlikuju poslovni rezultati poduzeća sa subvencijama u odnosu na subvencionirana brodogradilišta, dok se rezultati poduzeća sa subvencijama ne razlikuju značajno (na razini 5 posto značajnosti) od poslovnih rezultata Holdinga i HŽ-a s potporama.

S druge strane primljene subvencije pridonijele su njihovoj likvidnosti, odnosno sigurnosti poslovanja, što je nositeljima ekonomske politike važno jer je riječ o poduzećima s većim brojem zaposlenih (socijalni mir).

Ne manje bitno zapažanje jest da se specifična skupina javnih poduzeća izdvaja i po apsolutnim iznosima dobivenih subvencija (brodogradilišta iz prerađivačke djelatnosti, HŽ iz djelatnosti prometa, Holding iz djelatnosti upravljanja) ovisno o gospodarskoj djelatnosti te da postoje velike razlike između njih. S obzirom na to da sektorska pripadnost specifične skupine subvencioniranih javnih poduzeća nije bila u fokusu ovoga rada, preporuka je za buduća istraživanja.

Rezultati provedenog istraživanja potvrdili su da je država u promatranom razdoblju subvencijama izrazito podupirala specifična javna poduzeća. Međutim, promatrajući njihovu uspješnost u odnosu na ostala poduzeća, može se zaključiti da nisu polučili značajnije rezultate, osim ako je cilj ekonomske politike bio očuvanje radnih mjesta, odgoda nužnih restrukturiranja i bolnih rezova.

Vlasnički portfelj državnih poduzeća, poglavito specifične skupine, strateški je nejasan jer država kao vlasnik sudjeluje u različitim gospodarskih djelatnostima te bi se u budućnosti trebala odrediti u tom smjeru i svoje odluke aktivnije usmjeriti u horizontalne ciljeve. Mjerenje učinaka državnih subvencija svakako bi moglo pridonijeti pri strukturiranju optimalne politike državnih potpora i subvencija, a time i učinkovitije alokacija subvencija. 


\section{LITERATURA:}

1. Bajo, A., Zuber, L. i Primorac, M. (2017), Uspješnost financijskog poslovanja poduzeća u vlasništvu države. Fiscus, Institut za javne financije, Zagreb

2. Beason, R. i Weinstein, D. (1996). Growth, Economies of Scaleand Targeting in Japan (1955-1990), The Review of Economics and Statistics, 78(2), 286-295.

3. Bejaković, P., Vukšić, G. i Bratić, V. (2011). Veličina javnog sektora u Hrvatskoj. Hrvatska i komparativna javna uprava, 11(1), 99-125.

4. Bergstrom, F. (1998). Kapitalne potpore i učinak poduzeća. SSE/EFI Serija radnih knjiga u ekonomiji i financijama broj 285, Stockholm

5. Bernard, A. B. i Jensen, J. B. (2004). Exceptional exporter performance: cause, effect, or both?. Journal of international economics, 47(1), 1-25.

6. Buturac, G. (2014). Država i ekonomija: Gdje je Hrvatska?. Ekonomski pregled, 65(6), 513-540.

7. Crnković, B., Požega, Ž. i Karačić, D. (2011). Izazovi korporativnog upravljanja u državnim poduzećima - Hrvatske perspektive. Ekonomski vjesnik, XXIV(2), 279-292.

8. Financijska agencija (2015), http://www.fina.hr/gfi

9. Girma, S., Gorg, H. i Wagner, J. (2009). Subsidies and exports in Germany: First evidence from enterprise panel data. IZA Discussion Paper, No. 4076.

10. Griffiths, A. i Wall, S. (2004). Applied Economics. New York: Pearson Education.

11. Hrvatski sabor (2010). Izvješće o poslovanju trgovačkih društava od posebnog državnog interesa. Dostupno na http://www.sabor.hr/Default. aspx?art $=35628 \& \sec =2601 \& \mathrm{dm}=2$

12. Ministarstvo financija (2016). Dostupno na http://www.mfin.hr/drzavne-potpore

13. Ministarstvo pravosuđa (2017). Sudski registar. Dostupno na https://sudreg. pravosudje.hr/registar/f?p=150:28:0::NO:28:P28_SBT_MBS:080003463

14. Spevec, O. (2012). Reforma i modernizacija politike državnih potpora u EU i posljedice za Hrvatsku. Računovodstvo i financije, 58(9), 108-113.

15. Žagar, K. i Žager L. (2008). Analiza financijskih izvještaja. Zagreb: Masmedia.

16. Zakon o proračunu. Narodne novine, 87/08, 136/12 i 15/15.

17. Zelenika, R. i Toković, K. (2000). Pokazatelji uspješnosti i stabilnosti poslovanja prometnog poduzeća. Hrvatska gospodarska revija, 49(4), 8-18.

18. Žunić Kovačević, N. (2008). Problemi financiranja krupne gospodarske i urbane infrastrukture - o financiranju javnih poduzeća. Hrvatska javna uprava, 8(1), 205-228. 
PRILOG 1.

Korištene varijable i primijenjene transformacije

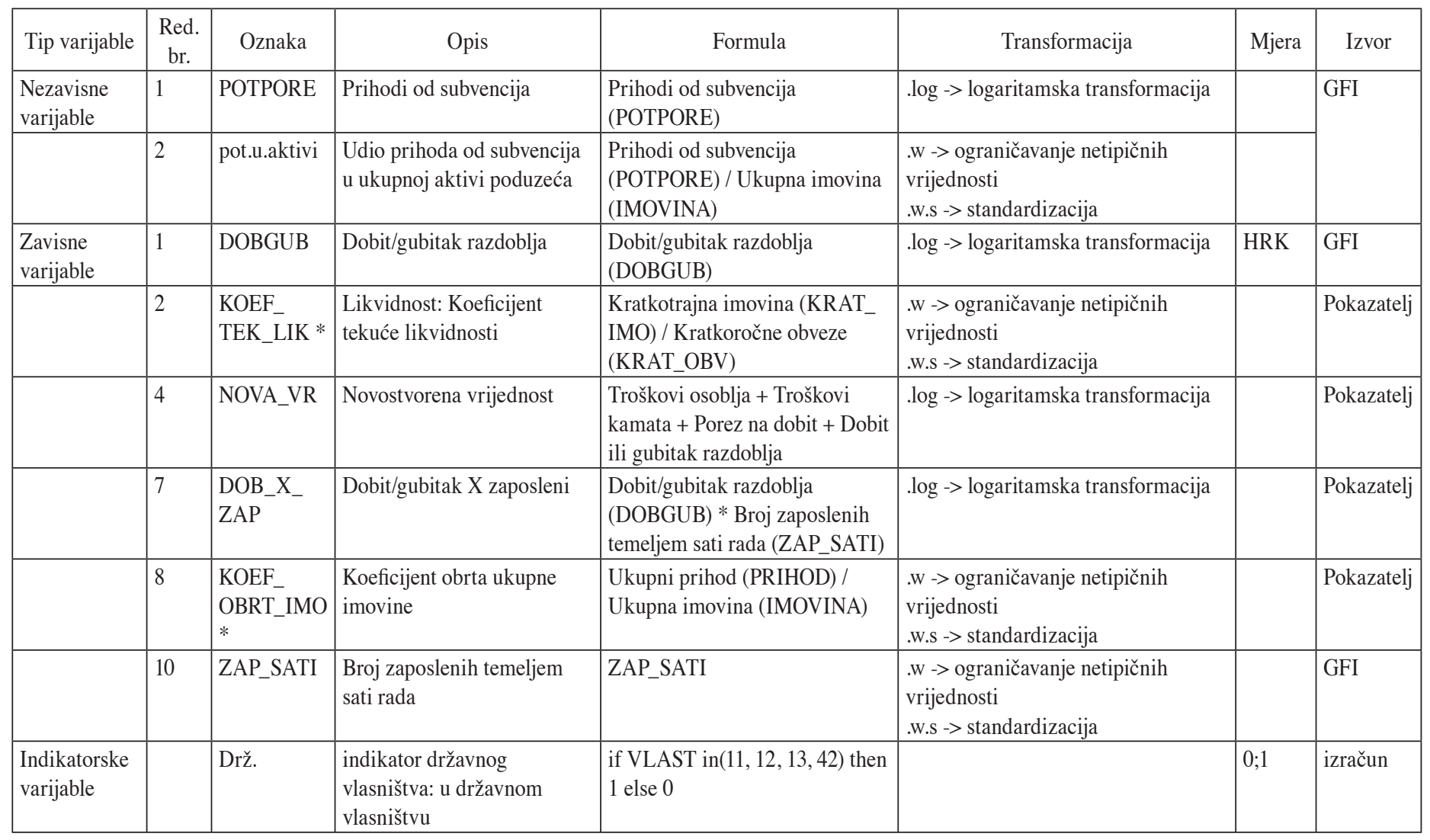




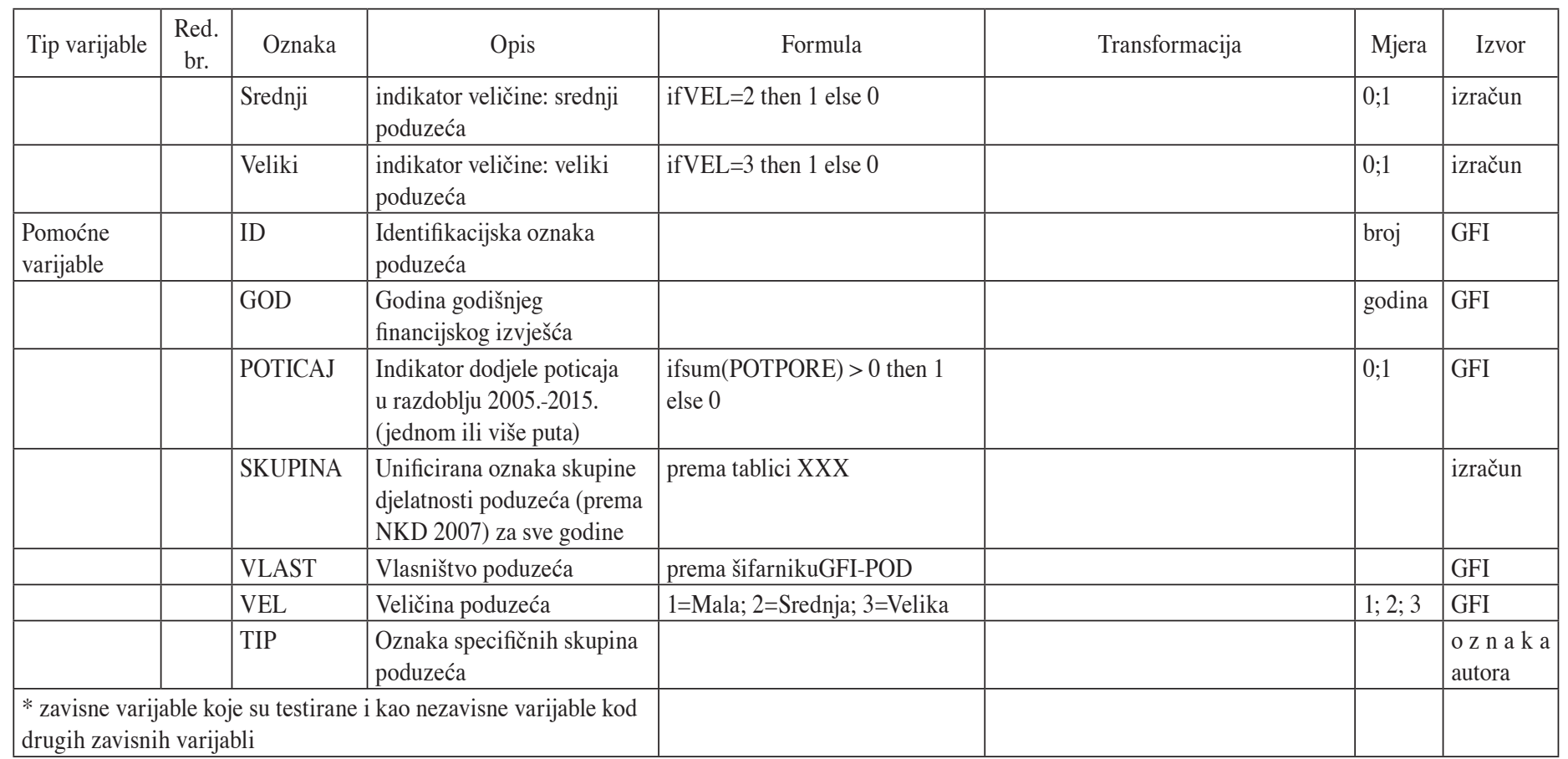




\title{
THE IMPACT OF THE SUBSIDIES ON THE BUSINESS PERFORMANCE OF THE SPECIFIC GROUPS OF CROATIAN PUBLIC ENTERPRISES
}

\author{
Summary
}

Given that the structure of Croatian state aid instruments over the EU member states is dominated by the representation of state subsidies, the aim of this paper is to analyse the impact of subsidies on the performance of a specific group of Croatian public companies in the period 20052015 compared in relation to other subsidized enterprises. These are companies that have changed their legal and economic identity (mergers, acquisitions, etc.) over the course of their lifetime and are mostly state-owned and have received significant amounts of government subsidies.

The data used in the analysis is data from the registry of the Financial Agency's annual financial statements. They have a panel data structure, and it is unbalanced panel, which assumes that companies that received subsidies in the observed period are observed only for the years in which they received them. The objective is to measure the impact of the subsidies received on the financial results in the years when they were awarded. As very few foreign and domestic researchers have addressed this topic, the contribution of this paper is to quantify relationships and test statistical models to determine the statistical link between the impact of subsidies on the financial performance of a specific group of public enterprises in an unbalanced panel of entrepreneurs and the correlation of independent variables and correlations of independent variables and independent with dependent variables. Two major independent variables were selected for assessing the impact of subsidies on the financial performance of a specific group of enterprises in the observed period, namely subsidy revenues and the share of subsidy revenues in the assets of an enterprise. While the dependent variables are: profit / loss for the period, newly created value, current liquidity ratio, asset turnover ratio and number of employees based on working hours. Based on the results of the analysis, it can be concluded that subsidies have an impact on the performance of a specific group of public companies in relation to the model estimate, in particular profit / loss for the period, newly created value, and at least to the number of employees based on working hours, suggesting a conclusion that a higher subsidies were given to companies with greater number of employees.

The results of the research should take into account the restriction resulting from the database itself, i.e. the lack of a clear AOP position on government subsidies in the annual financial statements (AOP position includes subsidies, grants, incentives, etc.) and only the available position was used.

Key words: public enterprises, specific group of public enterprises, state aid, government subsidies, business performance 